Universidade de Brasília

Faculdade de Direito

Curso de Graduação em Direito

\title{
A MODULAÇÃO DE EFEITOS NO CONTROLE DE CONSTITUCIONALIDADE COMO LIMITAÇÃO AO PODER DE TRIBUTAR
}

André Torres dos Santos

Brasília, Julho de 2011 


\section{André Torres dos Santos}

\section{A MODULAÇÃo DE EFEITOS NO CONTROLE DE CONSTITUCIONALIDADE COMO LIMITAÇÃO AO PODER DE TRIBUTAR}

André Torres dos Santos

Trabalho de conclusão de curso apresentado como requisito para a graduação no curso de bacharelado em Direito pela Faculdade de Direito da Universidade de Brasília - UnB.

Orientador: Tarcísio Vieira de Carvalho Neto

Brasília, Julho de 2011 


\section{RESUMO}

A proposta ora apresentada reside na tentativa de estabelecer elementos capazes de nortear possíveis propostas de sistematização do instituto da modulação de efeitos no controle de constitucionalidade, o que implica na análise da extensão das possibilidades de flexibilização do princípio da nulidade da lei declarada inconstitucional e da conseqüente atribuição de efeitos ex tunc à decisão tomada em sede de jurisdição constitucional. Buscar-se-á, tomando-se como ponto de partida os princípios e pressupostos informadores do Estado de Direito e restringindo-se o campo de análise ao Direito Tributário, ponderar a viabilidade - e até mesmo a necessidade - de utilização dessa técnica como forma de maximizar a eficácia de direitos fundamentais previstos no próprio texto constitucional, vinculando-a às justificativas históricas da própria existência legítima do Estado, tal como hoje considerado.

Palavras-chave: ESTADO DE DIREITO. LIMITAÇÃO DO PODER DO ESTADO. DIREITOS DO CIDADÃO. SEGURANÇA JURÍDICA. CONTROLE DE CONSTITUCIONALIDADE. MODIFICAÇÃO DE JURISPRUDÊNCIA. MODULAÇÃO DE EFEITOS. DIREITO TRIBUTÁRIO. 


\section{Índice de Siglas}

ADI - Ação Direta de Inconstitucionalidade

ADC - Ação Declaratória de Inconstitucionalidade

ADPF - Argüição de Descumprimento de Preceito Fundamental

COFINS - Contribuição para o Financiamento da Seguridade Social

CPC - Código de Processo Civil

CTN - Código Tributário Nacional

CF - Constituição Federal

FUNRURAL - Contribuição do Empregador Rural para a Seguridade Social

LC - Lei Complementar

IPI - Imposto sobre Produtos Industrializados

RE - Recurso Extraordinário

RREE - Recursos Extraordinários

STF - Supremo Tribunal Federal

STJ - Superior Tribunal de Justiça 


\section{Sumário}

Introdução .3

1 As garantias do cidadão como pressuposto do Estado de Direito...5

1.1 A doutrina de Carl Schmitt e as noções de Supremacia da Constituição e de Separação de Poderes como mecanismos de limitação do poder do Estado...5

1.2 A necessidade de proteção dos direitos e garantias do indivíduo: a sistematização dos direitos fundamentais

1.3 A garantia da segurança jurídica como pilar fundamental do Estado de Direito e o papel institucional dos Tribunais na formação da confiança no Direito

2. O papel do controle de constitucionalidade na concretização do Estado de Direito

2.1 Os controles difuso e concentrado de constitucionalidade e a possibilidade de modulação temporal de seus efeitos

2.2 Os fundamentos e pressupostos da doutrina prospectiva: modulação de efeitos como mecanismo de afirmação de direitos do cidadão...

2.3 O debate em torno da constitucionalidade do próprio instituto da modulação: ADI's n ${ }^{0}$ 2.154/DF e 2.258/DF

3. A modulação de efeitos em matéria tributária.

3.1 O contribuinte como cidadão e o princípio da proteção da confiança como corolário da segurança jurídica no Direito Tributário

3.2 Modulação de efeitos no controle de constitucionalidade em matéria tributária: análise crítica da sua evolução na jurisprudência do Supremo Tribunal Federal

3.2.1 O caso Prescrição Previdenciária: modulação de efeitos em benefício do Estado. 46

3.2.2 O caso COFINS - Sociedades Civis: recusa de modulação de efeitos em benefício dos contribuintes 50 
3.2.3 O caso FUNRURAL: recusa de modulação de efeitos em prejuízo do contribuinte.

4 A modulação de efeitos como garantia das limitações ao poder de tributar57

4.1 Os princípios da boa-fé, da irretroatividade e da proteção da confiança como limites constitucionais ao poder de tributar: possibilidade de modulação de efeitos em "viradas jurisprudenciais".

4.2 A necessidade de aplicação unilateral da doutrina prospectiva e sua utilização como mecanismo de concretização do princípio da segurança jurídica

Conclusão 66

Referências Bibliográficas 69 


\section{Introdução}

O debate acadêmico em torno do fenômeno do constitucionalismo passa, necessariamente, pelos aspectos sociais, políticos e econômicos que ensejaram a construção histórica do Estado de Direito, figurando como pressuposto de sua consolidação a garantia dos princípios e valores liberais burgueses pautados na afirmação do papel do indivíduo na sociedade e na conseqüente necessidade de limitar a atuação estatal em benefício da liberdade individual.

Uma vez consideradas como inerentes à própria existência do Estado, as garantias individuais - e a necessidade de sua proteção - implicam na necessária divisão do Poder do Estado em um sistema de competências circunscritas e delimitadas de forma a viabilizar o controle recíproco entre as diversas esferas de poder, permitindo-se, assim, o equilíbrio de forças necessário a impedir a sobreposição do Estado sobre o indivíduo.

Adotando como ponto de partida a clássica doutrina constitucional de Carl Schmitt, o presente trabalho buscará fundamento nas noções de Supremacia da Constituição e de nulidade da lei inconstitucional, que dela decorre, para indagar acerca da extensão dos efeitos temporais da declaração de inconstitucionalidade e da possibilidade de, diante da necessidade de maximizar a eficácia das normas e princípios contidos no próprio texto constitucional, limitar esses efeitos no tempo por meio da utilização da doutrina prospectiva, cujos elementos e pressupostos serão abordados adiante.

Nesse contexto, deve ser considerada a garantia fundamental da segurança jurídica como elemento central a ser utilizado no juízo de ponderação em torno da aferição da possibilidade - ou, até mesmo, da necessidade - de se proceder à modulação dos efeitos temporais de uma decisão tomada em sede de jurisdição constitucional.

Posta a tensão entre a nulidade da lei inconstitucional, decorrência lógica do próprio Estado de Direito em sua concepção clássica, e de sua incongruente convivência com possíveis violações de garantias fundamentais em virtude da 
adoção de efeitos ex tunc, típicos de atos nulos, buscar-se-á encontrar fundamentos que viabilizem, por meio da utilização de uma lógica inversa, garantir a Supremacia da Constituição a partir da relativização dos efeitos da nulidade, pautando-se, para tanto, no escopo precípuo do Estado de Direito tal como salientado por Carl Schmitt: limitar a atuação do Estado, revestindo-a de previsibilidade e controlando-a em nome da garantia dos direitos do cidadão.

Restringindo a análise à temática do direito tributário, cuja regulamentação, no direito brasileiro, encontra-se amplamente constitucionalizada, o presente trabalho tentará demonstrar que, especialmente nessa seara, a manipulação dos efeitos das declarações de inconstitucionalidade, seja em sede de controle difuso ou concentrado, pode exercer papel de suma importância na concretização dos princípios fundamentais que informam a base de um Estado de Direito.

Empreendendo-se uma análise crítica em torno da aplicação da doutrina prospectiva pela jurisprudência do Supremo Tribunal Federal, tentar-se-á identificar elementos capazes de nortear possíveis propostas de sistematização do instituto, o qual, independentemente de regulamentação, deve se pautar nos pressupostos e justificativas históricas do Estado de Direito, sob pena de ilegitimidade do próprio instituto em face da estrutura do ordenamento jurídico vigente. 


\section{As garantias do cidadão como pressuposto do Estado de Direito}

\subsection{A doutrina de Carl Schmitt e as noções de Supremacia da Constituição e de Separação de Poderes como mecanismos de limitação do poder do Estado}

As origens e justificativas históricas do Estado de Direito, tal como ele hoje se apresenta, convergem para a formação de uma mentalidade orientada para a proteção do indivíduo frente ao poder e aos abusos do Estado, o qual, até então, estava vinculado à idéia de Absolutismo, em que o indivíduo, em si, não figurava como elemento central de sua organização, mas, antes, era considerado como parte de um todo social, de uma coletividade uniforme, sujeita às conveniências e arbitrariedades do poder instituído. ${ }^{1}$

Em um contexto de consolidação da ideologia individualista trazida com as revoluções liberais burguesas do século XVIII, emergiu no cenário político de algumas nações européias a necessidade de se estabelecer, no campo da própria organização estatal, elementos que garantissem os valores e princípios liberais burgueses, elevando-os ao patamar de pressupostos da própria existência do Estado.

Tais pressupostos, comprometidos com a necessidade de afirmação do indivíduo perante o Estado, necessitavam estar vinculados a princípios e ideais que, na condição de manifestações da liberdade individual, estivessem fundados em uma base comum: a limitação do poder estatal.

Em sua clássica obra Teoria da Constituição², Carl Schmitt explica que o que se chamaria de "Estado de Estamentos", ou "Estado Feudal", verificado na Europa no final da idade média, possuía características e estruturação política

\footnotetext{
${ }^{1}$ Sobre a contraposição entre a ideologia holista, predominante na Idade Média, e a ideologia individualista, que emergiu no cenário ocidental com as revoluções liberais burguesas, ver: DUMONT, Louis. O individualismo: uma perspectiva antropológica da sociedade moderna. Tradução de Álvaro Cabral. Rio de Janeiro: Rocco, 1985.

2 SCHMITT, Carl; AYALA, Francisco (versão espanhola). Teoria de La Constitución. Alianza Editorial S.A., Madrid: 1996.
} 
baseadas em pactos (estipulaciones) que não passavam de meros conglomerados de direitos adquiridos e privilégios, inseridos em capitulações nas quais se afiançavam diversos interesses particulares.

Tais pactos, muito embora por vezes incluíssem limitações ao poder do príncipe e até mesmo o reconhecimento do direito de resistência armada, não podem ser considerados como Constituições de Estados, sendo um equívoco transladar os modernos conceitos do Direito político a tais relações medievais, na medida em que as estipulaciones não encerravam qualquer unidade política e sequer representavam uma decisão sobre o modo ou a forma de se estabelecer essa eventual unidade, elemento que figura como objeto precípuo das Constituições modernas.

No entanto, ainda que não contivessem em seu âmago qualquer elemento ideológico nesse sentido, tais estipulações estamentais foram tidas como ponto de referência pelos esforços constitucionais do século XIX, que a partir delas enxergaram um modelo de Constituição que viesse a limitar e a controlar o exercício do Poder. Tal modelo se consolidou com a eclosão da Revolução Francesa de 1789, marco do surgimento da Constituição moderna, na qual se vislumbravam elementos liberais e democráticos. 3

Sem pretender esmiuçar as conjunturas social, política e econômica relacionadas aos aspectos históricos que permitiram o desenvolvimento do moderno conceito de Constituição, importa ao presente estudo a demonstração de que tal conceito, ainda hoje existente, alinha-se à própria noção de Constituição trazida pelo Estado Burguês de Direito, cujo ideal consiste no controle da atividade estatal e na proteção do indivíduo e de seus valores tipicamente liberais. Ao discorrer sobre o conceito, Schmitt afirma:

"O conceito hoje dominante de Constituição é o ideal de Constituição do estado Burguês de Direito. (...) A particularidade de seu ideal consiste na adoção de uma organização de Estado a partir de um ponto de vista crítico e negativo frente ao

3 SCHMITT, op. cit., pgs. 66-79 
poder do Estado - proteção do cidadão contra o abuso do poder do Estado. Os meios e métodos de controle sobre o Estado se organizam mais que o próprio Estado; criam-se garantias contra ataques estatais, e introduzem-se freios ao exercício do poder público. Uma Constituição que não contivesse essas garantias próprias do Estado Burguês de Direito não poderia ser concebida, pois o Estado em si, sua unidade política, o que deve ser controlado, precisa existir de antemão ou ser criado simultaneamente. A tendência do Estado Burguês de Direito vai no sentido de deslocar o político, limitar por uma série de normas todas as manifestações da vida do Estado e transformar toda a atividade estatal em competências, limitadas em princípio, rigorosamente circunscritas". 4 (tradução livre)

Nesse contexto, constata o autor que o próprio Estado de Direito é um corolário das Constituições modernas, as quais, uma vez comprometidas com os princípios liberais burgueses (tais como a liberdade individual, a propriedade privada e a liberdade de contratar), colocam o Estado em uma posição de verdadeiro servidor da sociedade, devendo ser rigorosamente controlado.

É certo que, apesar de toda a juridicidade e a normatividade instituídas para viabilizar esse controle, o Estado, como tal, não foi desprovido de seu caráter político, sem o qual não haveria sequer a possibilidade de sua instituição. O que se pretende, ao afirmar que o controle estatal figura como pressuposto da própria existência do Estado de Direito, é tão somente demonstrar que as Constituições modernas, segundo seu dever histórico e seu esquema fundamental, pautam-se na liberdade burguesa e na finalidade de proteger os cidadãos contra abusos do poder público, em contraposição às superadas noções de Estado como um fim em si mesmo.

Posta a questão, importa resgatar a relevante distinção trazida por Schmitt entre os dois elementos basilares do Estado de Direito, os quais, por figurarem como conseqüências da própria liberdade burguesa e estarem presentes em todas as Constituições modernas, representam o ponto de partida para a sistematização de toda a estrutura teórica e organizacional do Estado de Direito. Schmitt os define como princípios de distribuição e de organização.

${ }_{4}^{4}$ SCHMITT, op. cit., pg. 62. 
Pelo princípio de distribuição se deve entender a esfera de liberdade atribuída ao indivíduo como um dado anterior ao Estado, sendo ilimitada em princípio, de forma que, em contrapartida, o poder do Estado de invadi-la seria limitado em princípio. Tal elemento encontra sua mais intensa expressão no rol de direitos fundamentais presente nas Constituições modernas, cuja natureza e importância serão tratados adiante.

O princípio de organização, por sua vez, deve funcionar como um viabilizador do princípio de distribuição, permitindo que ele seja concretizado por meio da divisão do poder do estado em um sistema de competências circunscritas. Trata-se da doutrina da Separação de Poderes, que tem por finalidade estabelecer freios e controles recíprocos entre as diversas esferas do poder instituído, visando ao estabelecimento de um equilíbrio de forças que impeça a sobreposição do Estado sobre o indivíduo.

Por meio desses dois elementos, Schmitt apresenta a afirmação de que direitos fundamentais e Separação de Poderes designam, em conjunto, o conteúdo essencial do Estado de Direito, que se faz presente em todas as Constituições modernas.

Desses elementos, decorrem consequiências importantes para a formação do Estado de Direito, como, por exemplo, a noção de superioridade da Lei segundo a qual não poderá o Estado interferir na esfera de liberdade individual senão em virtude de uma lei que assim determine - e a idéia de previsibilidade e delimitação de todas as manifestações de poder do Estado, que é pressuposto lógico para o exercício de qualquer controle sobre ele. Sobre essa última, afirma Schmitt que

\footnotetext{
"todas as atividades estatais, inclusive legislação e governo, podem se resumir a um funcionamento previamente calculável, segundo normas fixadas de antemão. Tudo se encontra previsto em um rol de competências, nunca ilimitadas em princípio, nem sequer as extremas, nem sequer a competência de determinar competências; nunca haverá plenitude do poder público, que terá sempre um poder controlável, cuja extrapolação possa dar ensejo a um procedimento judicial. Por isso, decorrem do sistema fechado do Estado burguês de Direito as exigências
} 
de legalidade, determinação de competências, mecanismos de controle e forma judicial. A Constituição aparece como a lei fundamental desse sistema de leis.” 5 (tradução livre).

Do pensamento do filósofo extrai-se a noção de Supremacia da Constituição, entendida como pedra fundamental do Estado de Direito na medida em que é fruto do poder constituinte originário, essência e manifestação do aspecto político acima mencionado, que não restou suprimido das Constituições modernas apesar do contexto de limitação do poder do Estado nelas contido.

A Supremacia da Constituição, portanto, no Estado de Direito, acaba figurando como pressuposto do sistema de organização estatal, na medida em que somente a Carta Política, na qual se estabelecem tais mecanismos de controle, pode representar o parâmetro, a base, o ponto de partida para o exercício desse controle.

A noção de Supremacia da Constituição, pressuposta por Schmitt ao considerá-la como "a lei fundamental do sistema de leis"6, foi concebida por Hans Kelsen em sua Teoria Pura do Direito7, a partir da metáfora no sentido de que o sistema de leis, abstratamente considerado, seria formado por uma pirâmide em que a Constituição, por seu caráter de norma fundamental, estaria no topo, subordinando, assim, todas as demais normas existentes no ordenamento jurídico aos princípios e valores nela estabelecidos. Adotando essa ficção, Schmitt empreende seu raciocínio da seguinte maneira:

"Se finge que, primeiro, a Constituição não é mais do que um sistema de normas legais; segundo, que esse sistema é fechado, e que, terceiro, é soberano, quer dizer, que nada pode corromper ou sequer influenciar por razões ou necessidades da existência política". ${ }^{8}$ (tradução livre)

\footnotetext{
5 SCHMITT, op. cit., pg. 142.

${ }^{6}$ Idem, ibidem.

7 KELSEN, Hans. Teoria Pura do Direito. Tradução: João Batista Machado. $5^{\mathrm{a}}$ ed. São Paulo: Martins Fontes, 1996.

${ }^{8}$ SCHMITT, op. cit., pg. 142.
} 
De acordo com o pensamento de Kelsen, o fundamento de validade de uma norma só pode estar vinculado a uma outra norma superior àquela, de forma que, em um sistema dinâmico, como os ordenamentos jurídicos, a norma que valha como fundamento de validade para todas as outras tem o caráter de normal fundamental. Desse contexto, surge a estrutura escalonada do sistema jurídico, a qual pode ser resumida pelo seguinte excerto:

\begin{abstract}
“A ordem jurídica não é um sistema de normas jurídicas ordenadas no mesmo plano, situadas umas ao lado das outras, mas é uma construção escalonada de diferentes camadas ou níveis de normas jurídicas. A sua unidade é o produto da relação de dependência que resulta do fato de a validade de uma norma, que foi produzida de acordo com outra norma, se apoiar sobre essa outra norma, cuja produção, por sua vez, é determinada por outra; e assim por diante, até chegar finalmente na norma fundamental - pressuposta. A norma fundamental hipotética, nesses termos - é, portanto, o fundamento de validade último que constitui a unidade desta inter-relação criadora.

Se começarmos a levando em conta apenas a ordem jurídica do Estado, a Constituição representa o escalão do direito positivo mais elevado". 9
\end{abstract}

Independentemente das críticas ${ }^{10}$ formuladas ao excessivo isolamento da Teoria de Kelsen, que se pretendia imune a quaisquer interferências de outras esferas da vida humana como a política, a moral e a economia, bem como às conseqüências nefastas de sua aplicação para conferir legitimidade às ditaduras anti-democráticas da primeira metade do século XX, busca-se utilizar, neste trabalho, tão somente a noção de Supremacia da Constituição que dela decorre, a qual permitirá, mais adiante, conceber-se os modelos de controle de constitucionalidade que serão objeto do presente estudo.

9 KELSEN, op. cit., pg. 240.

10 Sobre as críticas ao pensamento de KELSEN, ver: WARAT, Luís Alberto. Introdução Geral ao Direito: a epistemologia jurídica da modernidade. Vol. II, Porto Alegre: Fabris, 1995. Ao comentar a obra de Kelsen, WARAT afirma que tal autor exclui de seu objeto toda a ideologia e prática política. Ou seja: concebe o Direito de forma independente de qualquer elemento externo, como aspectos sociológicos, políticos ou psicológicos. Rejeita qualquer contribuição da Filosofia da Justiça, da moral ou da religião, assim como também refuta os princípios que regulam a constituição das ciências causais, além das categorias do pensamento jurídico clássico. Dessa forma, atribui ao Direito uma tarefa meramente descritiva, como se todo o conhecimento fosse a constatação da realidade existente por si só. 
Para além disso, importa esclarecer que do caráter de superioridade - ou supremacia - das normas constitucionais se pode extrair a idéia de controle do poder estatal, o qual também estará vinculado à Constituição e somente poderá agir dentro da esfera de competências rigidamente determinada pelo texto constitucional.

Importante destacar, neste ponto, que intimamente relacionada à noção de Supremacia da Constituição se encontra a idéia de Superioridade da Lei, que funciona como mecanismo de realização daquela. Segundo Schmitt, uma vez atribuído pela Carta Maior a competência de legislar a determinados indivíduos (legisladores), é importante que fique claro, por princípio, a circunstância de que o próprio legislador está ligado a sua própria lei e seu poder de legislar não é um meio para a arbitrariedade.

Para a concretização desse elemento, Schmitt sugere um conceito de Lei próprio do Estado de Direito, em que não se entenda por "Lei" todo e qualquer ato oriundo da atividade legislativa, mas apenas aqueles em que, como fruto da vinculação do legislador aos princípios, normas e valores postos na Constituição, manifestem-se sem distorções e não se confundam com atos de vontade, medidas direcionadas a particulares ou mandatos que possam ser destinados à garantia de vantagens ou privilégios de quaisquer natureza.

Tudo isso pressupõe, pois, que a Lei tenha um caráter geral, isto é, seja aplicável a todos, sem distinção. Estabelece-se, assim, o conceito de Lei típico do Estado de Direito, conforme definido por Schmitt:

\footnotetext{
"Superioridade da Lei significa, em última análise, que o próprio legislador está ligado a sua própria lei e seu poder de legislar não é um meio para a dominação arbitrária. A vinculação do legislador à lei é possível, sem embargo, apenas na medida em que a lei é uma regra com certas propriedades: equidade, razoabilidade, justiça etc. Todas estas propriedades assumem que a lei é uma Regra Geral." ${ }^{11}$ (tradução livre)
}

${ }^{11}$ SCHMITT, op. cit., pg. 150. 
Esse conceito de Lei como norma de caráter geral, tido por Schmitt como o conceito de Lei típico do Estado de Direito, figura como pressuposto de todos os outros elementos do Estado de Direito, considerado em sua estrutura orgânica, como o sistema de separação de poderes, as noções de liberdade burguesa e de igualdade perante a Lei e até mesmo a independência dos juízes. ${ }^{12}$ É dizer, por exemplo, que o sistema de separação de poderes só tem sentido enquanto se entenda "Lei" em caráter geral, de modo que o poder de legislar não sirva para o atendimento de fins ou interesses específicos (gerando uma sobreposição do Poder Legislativo em relação aos demais), bem como que a própria igualdade perante a Lei implica na adoção do conceito idealizado por Schmitt, na medida em que mandatos particulares ou direcionados não encerrariam qualquer igualdade.

Estabelecidas essas premissas, deve ser retomada a distinção acima mencionada entre os princípios de distribuição e de organização, os quais informam, em conjunto, os dois maiores pilares do Estado de Direito: direitos fundamentais e separação de poderes.

Nesse contexto, no que toca aos direitos fundamentais, importa dizer que a essência desses direitos se confunde com a própria essência do Estado de Direito, na medida em que o fundamento precípuo daqueles reside na proteção do cidadão face ao Estado, que, por sua vez, figura como a ratio essendi deste. Tais garantias funcionam, pois, como mecanismos de realização do Estado de Direito ou, em outras palavras, como elementos norteadores de toda a atividade de controle estatal.

Por figurar como importante elemento de argumentação, essencial para o escopo a que se busca no presente trabalho, a apresentação da temática relativa aos direitos fundamentais e de seu papel na concretização do Estado de Direito será abordada no próximo tópico. Por hora, demonstrar-se-á o papel da

${ }^{12}$ SCHMITT, op. cit., pgs. 158-162. 
separação de poderes, chamada por Schmitt de divisão de poderes ${ }^{13}$, na formação do Estado de Direito.

Segundo Schmitt, a chamada divisão de poderes consiste no "segundo princípio elementar do Estado de Direito próprio de toda Constituição liberal burguesa, destinado a assegurar, a pôr em prática, a moderação e o controle de todos os órgãos de poder do Estado". 14

É dizer que, por meio da compartimentalização do poder, permite-se o exercício do controle do Estado por cada uma de suas esferas, que se observam e fiscalizam reciprocamente sob a égide de um rol de competências rigidamente delineado pela Constituição.

Sem pretender enveredar sobre as origens e explicações históricas da doutrina da distinção de poderes, que remonta às idéias de equilíbrio e de freios $e$ contrapesos trazida por Bolingbroke, passa pelos pensamentos de Locke e Montesquieu e se consolida com a Constituição Francesa de 1791, ${ }^{15}$ pretende-se demonstrar, neste trabalho, que a sistemática da distinção funciona como um esquema ideal, essencialmente teórico-metodológico, que acaba por permitir o atendimento do fim a que se destina o próprio Estado de Direito: proteger os cidadãos contra eventuais extrapolações do Poder do Estado.

Justificando a afirmação de que a distinção de poderes seria apenas um procedimento teórico, ideal, Schmitt esclarece que essa esquematização, se considerada de forma absoluta e sem relativizações, levaria a se conceber uma separação rigorosa entre os diferentes poderes, que seriam consideradas, equivocadamente, como três organizações isoladas entre si. Segundo Schmitt,

"Conseqüência dessa separação rigorosamente praticada seria a de que os corpos legislativos não poderia ter influência nenhuma sobre o Governo Parlamentar, é

\footnotetext{
13 Schmitt explica que faz a opção pela nomenclatura "distinção de poderes" por ser a expressão mais geral e abrangente, entendendo que o termo "divisão de poderes" seria mais adequado para designar as subdivisões de um mesmo poder, enquanto o termo "separação de poderes" transmite a falsa impressão de que os três Poderes estatais possuiriam atuações completamente isoladas, o que não corresponde à realidade. Sobre o tema, conferir: SCHMITT, op. cit., pg. 188-189

14 SCHMITT, op. cit., Pg. 186

${ }^{15}$ Sobre a evolução histórica da doutrina da separação de poderes, ver: SCHMITT, op. cit. Pg. 186-189
} 
dizer, dependente da confiança da maioria da Corporação legislativa; contrariaria essa rigorosa separação, e por isso está excluída da Constituição dos Estados Unidos da América. Se poderia obter também, da necessidade da separação, a conseqüência de que tampouco poderia ter lugar qualquer controle judicial sobre os atos do Legislativo, de forma que a declaração judicial de inconstitucionalidade das leis, tal como praticada pela Suprema Corte dos Estados Unidos da América frente ao Legislativo, seria contrária ao esquema de separação de poderes. Nesses exemplos se mostra que com o sistema de separação de poderes não tratamos de uma organização histórica completa que foi praticada em qualquer lugar e à toda risca, mas apenas de um esquema teórico cuja construção nos permite aclarar o princípio de organização" ${ }^{16}$ (tradução livre)

Como se vê, a própria distinção de poderes tem lugar, como teoria, para fundamentar e instrumentalizar o princípio de distribuição, já visto acima, que representa um dos dois grandes elementos do Estado de Direito e decorre das primordiais intenções de garantir a liberdade burguesa e de proteger os direitos dos cidadãos frente ao Estado.

Vale ressaltar que, conforme salienta Schmitt, esse mecanismo de freios e contrapesos entre os poderes em busca de um equilíbrio de forças tem por finalidade, no Estado de Direito atual, compensar o predomínio dos corpos legislativos, os quais, em conseqüência da Supremacia da Lei e da garantia do conceito de Lei típico do Estado de Direito, têm uma natural tendência de sobreposição em relação aos demais. ${ }^{17}$

No entanto, para efeitos do presente estudo, importa tão somente a constatação de que a chamada Distinção de Poderes, além de ser considerada, em última análise, como um mecanismo de garantia dos direitos dos cidadãos por meio da limitação ao poder do Estado, fundamenta, justifica e autoriza o denominado controle de constitucionalidade, instituto cujas características e aspectos controvertidos serão abordados mais adiante.

\subsection{A necessidade de proteção dos direitos e garantias do indivíduo: a sistematização dos direitos fundamentais}

${ }^{16}$ SCHMITT, op. cit., pg. 189 
Pelo que já foi exposto em torno dos pressupostos e características do Estado de Direito, tais como concebidas pela ainda atual doutrina de Carl Schmitt, tem-se que a pretendida proteção do indivíduo e de sua liberdade em relação aos Poderes do Estado implica - e até mesmo pressupõe - no estabelecimento, pela própria Constituição, de um rol de direitos individuais tidos por fundamentais.

Consoante mencionado no tópico anterior, a inserção de uma declaração de direitos do cidadão no texto constitucional funciona como um elemento norteador da atividade de controle estatal, já que esse controle será exercido como forma de garantir a realização e/ou a proteção desses direitos. Nas palavras de Schmitt,

\begin{abstract}
"A declaração solene de direitos fundamentais significa o estabelecimento de princípios sobre os quais se apóia a unidade política de um povo, e cuja vigência se reconhece como o fundamento mais importante para o surgimento e a formação dessa unidade, fundamento que dá lugar à integração da própria unidade estatal". ${ }^{18}$ (tradução livre)
\end{abstract}

Constata-se, portanto, que o reconhecimento, pelo Estado, da existência de direitos fundamentais do cidadão é decorrência direta do princípio de distribuição, exposto acima, na medida em que visa a preservar elementos da liberdade do indivíduo que se apresentam acima de quaisquer bens jurídicos. Mais do que bens jurídicos, tais direitos são verdadeiras esferas de liberdade das quais, necessariamente, resultam direitos de defesa contra o poder do Estado. ${ }^{19}$

Em um esforço conceitual em torno da natureza desses direitos, Schmitt afirma que

\footnotetext{
"para se ter um conceito utilizável pela Ciência é preciso deixar afirmado que em um Estado burguês de Direito são direitos fundamentais somente aqueles que podem valer como anteriores e superiores ao Estado, aqueles que o Estado, antes de outorgá-los com fulcro em uma lei, reconhece-os como pré-existentes a ele
}

${ }^{17}$ SCHMITT, op. cit, pg. 198

${ }^{18}$ Idem, pg. 165

19 Idem, pg. 169 
próprio, só podendo neles penetrar em uma extensão mensurada em princípio, e dentro de um procedimento regulado." 20 (tradução livre).

O papel dos direitos fundamentais para o funcionamento e a organização da estrutura do Estado de Direito é de tão grande importância que se confunde com a sua própria existência, de forma que não se vislumbra, em um Estado de Direito, uma Constituição que não estabeleça um rol de direitos e garantias individuais e os eleve ao patamar de direitos fundamentais.

Isso porque a presença de uma declaração expressa de direitos fundamentais no texto constitucional, tal como hoje se verifica em todas as Constituições modernas, é a única forma de se conferir eficácia máxima aos pressupostos liberais burgueses que ensejaram a criação do Estado de Direito. Na doutrina brasileira, leciona-se que

\footnotetext{
"Correm paralelos no tempo o reconhecimento da Constituição como norma suprema do ordenamento jurídico e a percepção de que os valores mais caros da existência humana merecem estar resguardados em documento jurídico com força vinculativa máxima, indene às maiorias ocasionais formadas na efervescência de momentos adversos ao respeito devido ao homem.

(...) Os direitos fundamentais assumem posição de definitivo realce na sociedade quando se inverte a tradicional relação entre Estado e indivíduo e se reconhece que o indivíduo tem, primeiro, direitos e, depois, deveres perante o Estado, e que os direitos que o Estado tem em relação ao indivíduo se ordenam ao objetivo de melhor cuidar das necessidades dos cidadãos." ${ }^{21}$
}

Os elementos característicos dos direitos fundamentais, conforme salientado por Schmitt, relacionam-se à circunstância de que, em regra, esses direitos se revelam absolutos em princípio, o que importa dizer que seu conteúdo não decorre da Lei, mas, antes, orienta a elaboração e a aplicação da Lei, sendo que as possibilidades de ingerência estatal sobre eles sempre figurarão como regras de exceção, as quais, à luz do princípio de distribuição, são limitadas em princípio, mensuráveis e reguladas em termos gerais.

${ }^{20}$ SCHMITT, op. cit., pg. 169

${ }^{21}$ MENDES, Gilmar Ferreira; COELHO, Inocêncio Mártires; BRANCO, Paulo Gustavo Gonet. Curso de Direito Constitucional $1^{\mathrm{a}}$ ed., São Paulo: Saraiva, 2007, pgs. 221-223 
É certo que, hoje, não se concebe o caráter absoluto dos direitos fundamentais de forma inconteste, na medida em que se mostram possíveis, em determinadas situações, limitar-se a aplicação de um direito fundamental em conflito com outro valor da ordem constitucional, notadamente outro direito fundamental. No mesmo sentido, dada à característica da historicidade desses direitos, seu eventual caráter absoluto pode enfrentar mitigações em razão das mudanças de contexto histórico em que estão inseridos, podendo sofrer limitações e/ou modificações em seu conteúdo. ${ }^{22}$

No entanto, o que se pretende no presente estudo, por ora, reside tão somente na demonstração de que, independentemente da existência de exceções e relativizações, os direitos fundamentais figuram como a maior expressão dos objetivos do Estado de Direito, cujo elemento chave reside no controle das atividades estatais visando à proteção do indivíduo, colocado em primeiro plano após a ascensão da burguesia liberal nos séculos XVIII e XIX.

Postos na base do ordenamento, esses direitos acabam por trilhar os rumos do Estado na concretização de seu objetivo, além do que, tal como a distinção de poderes, também fundamentam a autorizam a atividade de controle de constitucionalidade das Leis e atos normativos emitidos pelo poder público.

\subsection{A garantia da segurança jurídica como pilar fundamental do Estado de Direito e o papel institucional dos Tribunais na formação da confiança no Direito}

Dentre o extenso rol de garantias e direitos fundamentais presente na Constituição brasileira, ocupam posição de destaque os diversos dispositivos em que, explícita ou implicitamente, assegura-se a segurança das relações jurídicas firmadas sob o manto do âmbito do ordenamento jurídico vigente.

\footnotetext{
${ }^{22}$ Sobre as características essenciais dos direitos fundamentais, ver MENDES, COELHO e BRANCO, op. cit., pgs. 229-243.
} 
Não são necessários maiores esforços para se concluir, a partir das noções de que o ideal do Estado de Direito consiste no controle da atividade estatal e na proteção do indivíduo e de seus valores liberais, que a previsibilidade da ação estatal figura como corolário lógico da própria estrutura do Estado.

Isso porque, como conseqüência do controle exercido sobre as ações estatais, tem-se que todas as suas atividades devem ser previsíveis e calculáveis por parte dos que estiverem sujeitos aos seus efeitos de forma a permitir que seja garantida a estabilidade das relações jurídicas, a qual, segundo a melhor doutrina, "constitui um valor fundamental de todo e qualquer Estado que tenha a pretensão de merecer o título de Estado de Direito". ${ }^{23}$

Conforme afirma Ingo Wolfgang Sarlet, a elevação do direito à segurança jurídica ao patamar de direito fundamental e, até mesmo antes disso, de um dos direitos humanos reconhecidos pelo Estado, insere-se no contexto pós Declaração de Direitos Humanos de 1948 e faz parte de um fenômeno verificado em quase todas as Constituições modernas e documentos internacionais, inclusive na Constituição brasileira de 1988, em que, não obstante inexistir referência expressa a esse direito (à exceção da menção genérica contida no caput do artigo $5^{\circ}$ ), acaba consagrando-o em inúmeras passagens de seu texto. ${ }^{24}$

Isso ocorre diante da necessidade - inerente aos pressupostos do Estado de Direito - de que o indivíduo, principalmente em relação a seus direitos fundamentais, seja protegido contra medidas que venham a reduzir ou suprimir situações jurídicas já consolidadas, importando em um retrocesso social, conforme definido por Ingo Sarlet. Segundo o autor,

“Certo é que havendo, ou não, menção expressa a um direito à segurança jurídica,
de há muito, pelo menos no âmbito do pensamento constitucional

${ }^{23}$ SARLET, Ingo Wolfgang. "A eficácia do direito fundamental à segurança jurídica: dignidade da pessoa humana, direitos fundamentais e proibição do retrocesso social no direito constitucional brasileiro". In: ROCHA, Carmen Lúcia Antunes (Coord.). Constituição e Segurança Jurídica: Direito adquirido, ato jurídico perfeito e coisa julgada. Belo Horizonte, ed. Fórum: 2004, pg. 87

24 Pode-se citar, apenas a título ilustrativo e sem pretensão exauriente, o próprio princípio da legalidade (art. $\left.5^{\circ}, \mathrm{II}\right)$, a proteção do direito adquirido, do ato jurídico perfeito e da coisa julgada (art. $5^{\circ}$, XXXVI), da irretroatividade da lei tributária (art. 150, III), entre outros. 
contemporâneo, se enraizou a idéia de que um autêntico Estado de Direito é sempre também - pelo menos em princípio e num certo sentido - um Estado da segurança jurídica, já que, do contrário, também o "governo das leis" (até pelo fato de serem expressão da vontade política de um grupo) poderá resultar em despotismo e toda a sorte de iniqüidades. Com efeito, a doutrina constitucional contemporânea, de há muito e sem maior controvérsia no que diz com este ponto, tem considerado a segurança jurídica como expressão inarredável do Estado de Direito, de tal sorte que a segurança jurídica passou a ter o status de subprincípio concretizador do princípio fundamental e estruturante do Estado de Direito. Assim, para além de assumir a condição de direito fundamental da pessoa humana, a segurança jurídica constitui simultaneamente princípio fundamental da ordem jurídica estatal e, para além desta, da própria ordem jurídica internacional." 25

Do fragmento mencionado, extrai-se ainda a constatação - atualmente bastante difundida - de que a segurança jurídica, para além de um direito fundamental, caracteriza-se como elemento de justificação e de integração do próprio Estado de Direito, que não pode ser concebido sem esse pressuposto nuclear.

Nesse contexto, são extraídos do princípio da segurança jurídica dois subprincípios de fundamental importância para a compreensão do fenômeno jurídico, quais sejam, o da proteção da confiança e o da proibição do retrocesso, os quais decorrem implicitamente do sistema constitucional. Pautado em lições de J.J. Gomes Canotilho²6, Sarlet salienta que, por força desses princípios, todos os órgãos do Estado devem praticar atos que estejam lógica e sistematicamente comprometidos com seus atos anteriores. Confira-se:

\footnotetext{
"Os órgãos estatais, especialmente como corolário da segurança jurídica e proteção da confiança, encontram-se vinculados não apenas às imposições constitucionais no âmbito da sua concretização no plano infraconstitucional, mas estão sujeitos a uma certa auto-vinculação em relação aos atos anteriores. Esta, por sua vez, alcança tanto o legislador, quanto os atos da administração e, em certa medida, dos órgãos jurisdicionais (...)". ${ }^{27}$
}

25 SARLET, ob. cit., pg. 90-91

${ }^{26}$ Cf. CANOTIlHO, José Joaquim Gomes. Direito Constitucional e Teoria da Constituição. $3^{\text {a }}$ ed., Coimbra: Almedina, 1999.

27 SARLET, ob. cit., pg. 110 
Para o objetivo almejado neste trabalho, revela-se de fundamental importância a consideração de que também os órgãos do Poder Judiciário, na apreciação da constitucionalidade das leis emanadas pelo Legislativo, devem observar os impactos de um eventual reconhecimento da inconstitucionalidade de uma norma sobre situações já consolidadas com base nos efeitos por ela produzidos até a sua extinção do mundo jurídico.

Com efeito, conforme afirmado pelo mencionado autor, os postulados da proteção da confiança e da proibição do retrocesso atuam como importantes elementos para a aferição da legitimidade constitucional de determinadas leis ou atos normativos que porventura venham, por exemplo, a ostentar caráter retroativo. É que, nesses casos, a necessidade de se garantir estabilidade às relações jurídicas permite que se estabeleça um certo grau de proteção, até mesmo, às expectativas de direitos, impedindo que uma legislação superveniente com efeitos retroativos possa frustrar posições jurídicas cuja gênese já se iniciou.

Nesse sentido, resgatando orientações do Tribunal Constitucional Alemão, Sarlet ressalta que,

\footnotetext{
"ainda que a doutrina e a jurisprudência constitucional tenham aplicado a proteção da confiança usualmente no contexto da proteção dos direitos adquiridos e em situações onde estavam em causa medidas de cunho retroativo (...), também é verdade que por força da proteção da confiança e do princípio da proporcionalidade (ambos deduzidos do Estado de Direito), o Tribunal Constitucional Federal da Alemanha, em reiterada jurisprudência, reconhece um certo grau de proteção até mesmo para as expectativas de direitos, exigindo, nesta hipótese, pelo menos a adoção de razoáveis regras de transição (ainda que mediante a concessão de ampla liberdade para o legislador), [sob] pena de inconstitucionalidade.

Como concretização do princípio da segurança jurídica, o princípio da proteção da confiança serve como fundamento para a limitação de leis retroativas que agridem situações fáticas já consolidadas (retroatividade própria), ou que atingem situações fáticas atuais, acabando, contudo, por restringir posições jurídicas geradas no passado (retroatividade imprópria), já que a idéia de segurança jurídica pressupõe a confiança na estabilidade de uma situação legal atual”. ${ }^{28}$
}

${ }^{28}$ SARLET, ob. cit., pg. 118 
Dessa forma, a concretização desses sub-princípios da segurança jurídica pelo Estado, inclusive pelo Judiciário, acaba por representar um mecanismo de realização de outro princípio, qual seja, o da maximização da eficácia das normas de direitos fundamentais. 29

Trazendo o problema para o campo do controle de constitucionalidade exercido pelo Poder Judiciário, vislumbra-se que, em meio ao papel constitucional atribuído aos Tribunais, surge um incômodo dualismo entre a noção clássica de nulidade da lei declarada inconstitucional (o que implica no reconhecimento dos efeitos ex tunc da declaração, conforme mencionado acima) e a necessidade de se preservar, em nome da segurança jurídica, relações e expectativas firmadas durante o período de vigência da referida Lei.

José Manuel Bandrés, ao discorrer sobre o papel institucional dos Tribunais sob a ótica da realidade espanhola, afirma que "a força dos tribunais tem sido, em todos os tempos, a maior garantia que se pode oferecer à independência individual" (tradução livre). ${ }^{30}$

Com efeito, uma vez garantidos os pressupostos democráticos que viabilizem a independência do juiz, o Poder Judiciário passa a representar, aos olhos dos cidadãos, o mecanismo mais eficaz de controle dos abusos eventualmente perpetrados pelo Estado, o que justifica seja depositada uma grande confiança nesse Poder, mormente ao se considerarem as funções de pacificação social e de estabilização de expectativas normativas a ele atribuídas.

No Brasil, como na maioria dos sistemas constitucionais existentes nas democracias modernas, ao Poder Judiciário é atribuída a função de legítimo intérprete dos atos emanados do Poder Legislativo, de forma que o conteúdo da norma, em si, é definido pelos juízes e tribunais competentes para interpretá-la. Em outras palavras, por meio da atividade interpretativa, acaba-se por definir o

\footnotetext{
${ }^{29} \mathrm{O}$ qual pode ser extraído, na Constituição brasileira, do próprio parágrafo primeiro do artigo $5^{\mathrm{o}}$, que encerra um mandado de otimização das normas de direitos fundamentais. Sobre o tema, conferir SARLET, Ingo Wolfgang. A eficácia dos direitos fundamentais. $4^{\mathrm{a}}$ ed., Porto Alegre: Livraria do Advogado, 2004.

30 BANDRÉS, José Manuel. Poder Judicial y Constitución. Barcelona: Casa Editorial, 1987, pg. 75
} 
conteúdo efetivamente existente na norma jurídica, tanto constitucional quanto infraconstitucional.

Nesse sentido, em estudo sobre a hermenêutica jurídica e o papel do intérprete na construção do significado da norma, Eros Roberto Grau corrobora o entendimento de que a norma nada mais é do que a interpretação a ela conferida, sendo que, inexistente a atividade interpretativa, sequer haveria conteúdo normativo. Conforme aduz,

\begin{abstract}
“A interpretação é um processo intelectivo através do qual, partindo de fórmulas lingüísticas contidas nos textos, enunciados, preceitos, disposições , alcançamos a determinação de um conteúdo normativo . (...) Interpretar é atribuir um significado a um ou vários símbolos lingüísticos escritos em um enunciado normativo. O produto do ato de interpretar, portanto, é o significado atribuído ao enunciado ou texto (preceito, disposição).

(...) As disposições são dotadas de um significado, a elas atribuído pelos que operaram no interior do procedimento normativo, significado que a elas desejaram imprimir. Sucede que as disposições devem exprimir um significado para aqueles aos quais são endereçadas. Daí a necessidade de bem distinguirmos os significados imprimidos às disposições (enunciados, textos), por quem as elabora e os significados expressados pelas normas (significados que apenas são revelados através e mediante a interpretação, na medida em que as disposições são transformadas em normas).

(...) A interpretação, destarte, é meio de expressão dos conteúdos normativos das disposições, meio através do qual pesquisamos as normas contidas nas disposições. Do que diremos ser - a interpretação - uma atividade que se presta a transformar disposições (textos, enunciados ) em normas . Observa Celso Antônio Bandeira de Mello (...) que '(...) é a interpretação que especifica o conteúdo da norma. Já houve quem dissesse, em frase admirável, que o que se aplica não é a norma, mas a interpretação que dela se faz. Talvez se pudesse dizer: o que se aplica, sim, é a própria norma, porque o conteúdo dela é pura e simplesmente o que resulta da interpretação. De resto, Kelsen já ensinara que a norma é uma moldura. Deveras, quem outorga, afinal, o conteúdo específico é o intérprete.

As normas, portanto, resultam da interpretação. E o ordenamento, no seu valor histórico-concreto, é um conjunto de interpretações , isto é, conjunto de normas . O conjunto das disposições (textos, enunciados ) é apenas ordenamento em potência, um conjunto de possibilidades de interpretação, um conjunto de normas potenciais. O significado (isto é, a norma) é o resultado da tarefa interpretativa.

(...) Vale dizer: o significado da norma é produzido pelo intérprete. (...) As disposições , os enunciados, os textos, nada dizem; somente passam a dizer algo quando efetivamente convertidos em normas (isto é, quando - através e mediante a interpretação - são transformados em normas ). Por isso as normas resultam da
\end{abstract}


interpretação , e podemos dizer que elas, enquanto disposições , nada dizem elas dizem o que os intérpretes dizem que elas dizem (...)”. ${ }^{31}$

Por essa razão, o abalo à confiança dos cidadãos por parte dos próprios órgãos jurisdicionais acaba por representar uma violação ao princípio da segurança jurídica ainda mais grave do que aquele cometido pelos demais poderes do Estado. Isso porque, ao se alterar uma determinada interpretação conferida a uma certa norma, modifica-se, em última análise, a própria norma, de forma que a sua aplicação retroativa, por exemplo, importaria em uma grande insegurança, abalando o elemento da previsibilidade da ação estatal.

Sobre o tema, Diego Diniz Ribeiro salienta que a interpretação conferida a uma norma pelo Poder Judiciário representa uma opção legítima por um dos sentidos possíveis, o que necessariamente acaba por orientar as expectativas dos jurisdicionados, especialmente em virtude do caráter de definitividade e de oponibilidade a terceiros da qual se reveste uma decisão judicial.

\begin{abstract}
"Ao decidir, o Poder Judiciário cria norma jurídica, afastando as outras variáveis de interpretação possíveis e delimitando aquela que deve ser seguida pelo jurisdicionado, o que, sem dúvida, acaba por criar uma expectativa jurídica a ser respeitada. As decisões judiciais têm uma natureza sintética, atuando como redutoras de complexidade, na medida em que afastam as outras interpretações possíveis que permeiam a norma jurídica sub judice.

(...) Nada mais lógico, então, que as normas veiculadas pelo Poder Judiciário sejam capazes de gerar expectativas e, por conseguinte, orientar o sentido a ser tomado pelos jurisdicionados em questões similares às já decididas. Esta capacidade das decisões judiciais de gerar expectativas ganha ainda mais força quando veiculada, em casos idênticos, de modo uniforme e repetidas vezes. Nessa hipótese forma-se a jurisprudência." 32
\end{abstract}

Disso se extrai que os juízes e Tribunais, em um Estado de Direito, possuem um papel fundamental na formação da confiança no Direito e, por essa

\footnotetext{
${ }^{31}$ GRAU, Eros Roberto. Ensaio e discurso sobre a Interpretação/Aplicação do Direito, 2 ${ }^{a}$ Ed., São Paulo: Malheiros: 2003

$3^{2}$ RIBEIRO, Diego Diniz. A Modulação de Efeitos no Controle de Constitucionalidade em Matéria Tributária e a Jurisprudência do STF. In: Revista Dialética de Direito Tributário. São Paulo: Dialética, n. 178, Julho de 2010, pg. 29-30
} 
razão, devem empreender sua atividade interpretativa de forma lógica e coerente.

Surge, neste ponto, um interessante debate em torno da possível tensão entre a necessidade de garantia da segurança jurídica, conforme exposto, e a noção clássica de nulidade da lei inconstitucional que, por decorrer da noção de Supremacia da Constituição, importa na sua invalidade desde a origem, como se nunca tivesse produzido efeitos. Indaga-se, portanto, como deve proceder o Judiciário, por exemplo, em uma hipótese de vir a ser reconhecida a inconstitucionalidade de uma norma que, até então, era tida por constitucional, válida e aplicável, gerando direitos, deveres e expectativas legítimas a todos os sujeitos passivos de suas disposições.

Consoante será desenvolvido adiante, o princípio da segurança jurídica deve nortear o reconhecimento da possibilidade de relativização desses efeitos $e x$ tunc (retroativos) da declaração de (in)constitucionalidade. Trata-se da possibilidade de modulação dos efeitos das decisões proferidas em sede de controle de constitucionalidade. 
2. O papel do controle de constitucionalidade na concretização do Estado de Direito

\subsection{Os controles difuso e concentrado de constitucionalidade e a possibilidade de modulação temporal de seus efeitos}

Em uma ordem jurídica constitucional, o controle de constitucionalidade figura como elemento central na concretização da Supremacia da Constituição, na medida em que estabelece mecanismos capazes de viabilizar a compatibilização, ainda que forçada, das leis e atos normativos editados pelo Poder Público com as normas e princípios contidos no texto constitucional. Em obra coletiva sobre o direito constitucional brasileiro, Gilmar Ferreira Mendes salienta que

\footnotetext{
"O reconhecimento da supremacia da Constituição e de sua força vinculante perante os Poderes Públicos torna inevitável a discussão sobre formas e modos de defesa da Constituição e sobre a necessidade de controle de constitucionalidade dos atos do Poder Público, especialmente de leis e atos normativos". 33
}

Foi no célebre julgamento do leading case Marbury $v$. Madison34, em 1803, pela Suprema Corte norte-americana, que primeiro se cogitou da possibilidade de o Judiciário exercer algum tipo de controle jurisdicional sobre os atos do Poder Executivo (tanto em relação à constitucionalidade ou à legalidade) e, consequentemente, da possibilidade de a Suprema Corte deixar de aplicar, com base nesse controle, uma lei que seja considerada inconstitucional.

Nesse julgamento emblemático, John Marshall, Presidente da Suprema Corte americana (Chief Justice), levou a Corte a afirmar seu poder de exercer o controle de constitucionalidade por meio do desenvolvimento de fundamentos em torno das noções de supremacia da constituição, de nulidade da lei

33 MENDES, COELHO e BRANCO, op. cit., pg. 954

34 Sobre os detalhes do caso e do julgamento, ver BARROSO, Luís Roberto. O controle de constitucionalidade no direito brasileiro. $3^{\text {a }}$ Ed., revista e atualizada - São Paulo: Saraiva: 2008, pg. 3-10 
inconstitucional dela decorrente e de atribuição, ao Poder Judiciário, do papel de intérprete final da Constituição.

Luís Roberto Barroso, comentando a importância histórica e as conseqüências de Marbury v. Madison para o constitucionalismo moderno, afirma que

\begin{abstract}
Marbury $v$. Madison, portanto, foi a decisão que inaugurou o controle de constitucionalidade no constitucionalismo moderno, deixando assentado o princípio da supremacia da Constituição, da subordinação a ela de todos os Poderes estatais e da competência do Judiciário como seu intérprete final, podendo invalidar os atos que lhe contravenham. Na medida em que se distanciou no tempo da conjuntura turbulenta em que foi proferida e das circunstâncias específicas do caso concreto, ganhou maior dimensão, passando a ser celebrada universalmente como o precedente que assentou a prevalência dos valores permanentes da Constituição sobre a vontade circunstancial das maiorias legislativas. 35
\end{abstract}

À luz dessas circunstâncias, construiu-se a noção de que em um Estado de Direito, nos termos em que acima delineado, essa atividade de controle de constitucionalidade das normas hierarquicamente inferiores à Constituição é atribuída, na distinção de poderes, ao Poder Judiciário. Por meio de sua função jurisdicional, cabe a esse Poder, seja em relação a um caso concreto em que se pretende aplicar determinada norma (controle difuso), seja em relação a um questionamento in abstrato em torno da constitucionalidade dessa norma (controle concentrado), dizer quanto à sua adequação ao sistema constitucional vigente.

No primeiro caso, também denominado controle concreto de constitucionalidade, de origem norte-americana, permite-se que qualquer juiz ou tribunal, em qualquer instância, declare a inconstitucionalidade de determinada norma, de forma incidental, para deixar de aplicá-la ao caso concreto posto à sua apreciação. Conforme leciona Luís Roberto Barroso, 
O controle incidental de inconstitucionalidade somente pode se dar na tutela de uma pretensão subjetiva. $\mathrm{O}$ objeto do pedido não é o ataque à lei, mas a proteção de um direito que seria por ela afetado. Havendo situação concreta, é indiferente a natureza da ação ou do procedimento. O que não é possível é pretender a declaração de inconstitucionalidade de uma lei em tese, fora de uma lide, de uma disputa entre partes. 36

Trata-se, pois, de um controle de constitucionalidade exercido, necessariamente, a título de questão prejudicial, isto é, como pressuposto lógico e necessário da solução do problema principal a ser decidido, de forma que, antes de decidir acerca do direito em discussão, o órgão jurisdicional terá que emitir juízo sobre a constitucionalidade da norma a ser aplicada.

Já o controle concentrado, de origem austríaca, é exercido a partir da análise de uma norma em abstrato, constituindo uma via atípica de jurisdição, na medida em que não visa a solucionar qualquer lide ou conflito de interesses entre duas partes com pretensões antagônicas, quer dizer, não existe um litígio ou situação concreta a ser solucionada pelo órgão julgador.37

Nessa modalidade de controle de constitucionalidade, o objeto principal do pronunciamento do Judiciário é a própria lei, em si, em tese, de forma que, contrariamente ao que ocorre no controle difuso, a discussão quanto à constitucionalidade da norma figura como a questão central a ser enfrentada, e não meramente prejudicial à sua aplicação a determinado caso concreto.

No entanto, sem pretender esmiuçar as características de cada uma das modalidades (ambas adotadas pelo Direito Constitucional brasileiro, considerado misto $)^{38}$, importa ao presente estudo, por ora, tão somente a consideração de que,

\footnotetext{
35 BARROSO, op. cit., pg. 10

${ }^{36}$ BARROSO, op. cit., pg. 83

37 BARROSO, op. cit., pg. 145

38 Sobre a adoção, no Brasil, de um modelo misto de controle de constitucionalidade, ver MENDES, COELHO e BRANCO, op. cit.,pg. 955, em que se leciona que "o controle misto de constitucionalidade congrega os dois sistemas de controle, o de perfil difuso e o de perfil concentrado. Em geral, nos modelos mistos defere-se aos órgãos ordinários do Poder Judiciário a prerrogativa de afastar a aplicação da lei nas ações e processos judiciais, mas se reconhece a determinado órgão de cúpula - Tribunal Supremo ou Corte Constitucional - a competência para proferir decisões em determinadas ações de perfil abstrato ou concentrado".
} 
em quaisquer das formas de controle, tem-se que a eficácia temporal das decisões importa, em princípio, na adoção de efeitos retroativos (ex tunc).

Isso porque adotou-se, no direito constitucional brasileiro, a teoria da nulidade da lei inconstitucional, segundo a qual decisão que reconhece a inconstitucionalidade da norma é de natureza declaratória, limitando-se a reconhecer um vício pré-existente e, portanto, capaz de invalidá-la desde o seu nascimento.

O reconhecimento da nulidade da norma declarada inconstitucional, conforme amplamente difundido na doutrina nacional e internacional, figura como corolário lógico da própria Supremacia da Constituição abordada anteriormente, de forma que, caso fosse possível admitir a aplicação de uma lei com ela incompatível, não haveria que se falar em supremacia de suas disposições. Em conseqüência, ao menos a princípio, tem-se que todas as relações jurídicas firmadas com base numa lei inconstitucional devem ser desconstituídas integralmente, retornando ao status quo ante, eis que, para o sistema jurídico como um todo, essa norma nunca existiu.

Ocorre, no entanto, que a aplicação exacerbada dessa teoria pode acarretar prejuízos à própria efetividade das normas contidas da Constituição, dentre elas o postulado da segurança jurídica, acima tratado, e os princípios a ela relacionados como os da boa-fé, da proteção da confiança, do direito adquirido e até mesmo da coisa julgada.

Nesse sentido e diante da complexidade das relações sociais, econômicas e políticas que floresceram com a consolidação do Estado Burguês de Direito, surgiu no constitucionalismo moderno a necessidade de se admitir, em certas hipóteses, o temperamento nulidade da lei inconstitucional, suprimindo ou atenuando, conforme o caso, os efeitos retroativos do pronunciamento de inconstitucionalidade. 39 Sobre o caráter excepcional da possibilidade de o

39 BARROSO, op. cit., pgs. 20-24 
Tribunal Constitucional modular os efeitos de suas decisões em sede de controle de constitucionalidade, diz-se que

\begin{abstract}
"Tal como observado, o princípio da nulidade continua a ser a regra também no direito brasileiro. $\mathrm{O}$ afastamento de sua incidência dependerá de um severo juízo de ponderação que, tendo em vista análise fundada no princípio da proporcionalidade, faça prevalecer a idéia de segurança jurídica ou outro princípio constitucionalmente importante, manifestado sob a forma de interesse social relevante. Assim, aqui, como no direito português, a não-aplicação do princípio da nulidade não há de se basear em consideração de política judiciária, mas em fundamento constitucional próprio.

O princípio da nulidade somente há de ser afastado se puder demonstrar, com base numa ponderação concreta, que a declaração de inconstitucionalidade ortodoxa envolveria o sacrifício da segurança jurídica ou de outro valor constitucional materializável sob a forma de interesse social." 40
\end{abstract}

Nota-se, a partir do excerto acima, a existência de uma bem lançada preocupação em torno das especificidades das hipóteses em que essa técnica poderá ser utilizada e da precisa delimitação do papel da Corte Constitucional ao decidir pela modulação temporal dos efeitos de suas decisões.

Tal preocupação se justifica em razão de que o legislador pátrio, ao inserir no cenário legislativo a possibilidade expressa de se empreender essa modulação, cuidou de utilizar, talvez propositalmente, conceitos e expressões de conteúdo semântico consideravelmente amplo, deixando ao Poder Judiciário, por meio da competência que lhe é atribuída segundo a Distinção de Poderes, o pleno exercício de sua atividade interpretativa.

Tais previsões foram introduzidas nas Leis $\mathrm{n}^{0} \mathrm{~s}$ 9.868/99 e 9.882/99, que regulamentam o controle concentrado de constitucionalidade no Brasil, ou seja, as Ações Diretas de Constitucionalidade e de Inconstitucionalidade (ADI e ADC) e a Argüição de Descumprimento de Preceito Fundamental (ADPF), o que foi feito, respectivamente, em seus artigos 27 e 11, cujo idêntico teor se transcreve a seguir:

${ }^{40}$ MENDES, COELHO e BRANCO, op. cit.,pg. 1204 


\begin{abstract}
"Ao declarar a inconstitucionalidade de lei ou ato normativo, e tendo em vista razões de segurança jurídica ou de excepcional interesse social, poderá o Supremo Tribunal Federal, por maioria de dois terços de seus membros, restringir os efeitos daquela declaração ou decidir que ela só tenha eficácia a partir de seu trânsito em julgado ou de outro momento que venha a ser fixado"
\end{abstract}

Da leitura dos dispositivos, constata-se que o legislador pretendeu atribuir ao Supremo Tribunal Federal a competência para, em certas situações, restringir os efeitos de uma decisão (limitando o seu alcance), impedir a sua retroatividade sobre relações jurídicas já consolidadas (fazendo-a incidir a partir de seu trânsito em julgado) ou, até mesmo, dilatá-los no tempo, fixando um termo futuro para que a norma deixe de produzir os seus efeitos.

Entretanto, é importante deixar claro, na linha do pensamento de Luís Roberto Barroso, que, contrariamente ao que possa parecer à primeira vista, não se trata de uma ponderação entre a segurança jurídica e/ou o interesse social e o princípio da Supremacia da Constituição. Este, por ser fundamento da própria existência do Estado de Direito e, conseqüentemente, do controle de constitucionalidade, jamais poderia ser ponderado ou afastado sem que restasse comprometida a unidade do sistema jurídico vigente. ${ }^{41}$

$\mathrm{O}$ que se faz, ao modular os efeitos das decisões quanto à constitucionalidade de uma norma, consiste na "ponderação entre a norma violada e as normas constitucionais que protegem os efeitos produzidos pela lei inconstitucional" 42 , isto é, protege-se a concretização dos próprios preceitos que garantem a Supremacia da Constituição, tais como os já mencionados acima.

Dito isso, importa esclarecer que, muito embora existam fundados questionamentos em torno da constitucionalidade desses dispositivos que permitem a modulação temporal dos efeitos das decisões tomadas pelo Supremo Tribunal Federal, os quais serão abordados no próximo tópico, as principais inquietações doutrinárias - hoje já superadas - sempre se deram quanto à

${ }^{41}$ BARROSO, op. cit., pg. 199

42 idem, pg. 200 
possibilidade de aplicação dessa técnica às decisões tomadas em sede de controle difuso de constitucionalidade.

Contudo, não obstante a doutrina clássica tenha estabelecido, dentre as características do controle difuso de constitucionalidade expostas acima, a eficácia inter partes das decisões nele proferidas, certo é que vem se verificando nos sistemas mistos, como o brasileiro, uma crescente aproximação entre os institutos de controle concentrado e difuso, o que pode ser verificado, no Brasil, a partir da criação da sistemática da repercussão geral nos julgamentos de recursos extraordinários pelo Supremo Tribunal Federal, assunto que, por se distanciar da temática aqui proposta, não será abordado no presente trabalho. 43

Por ora, a menção ao instituto da repercussão geral se justifica para demonstrar o fenômeno ao qual Gilmar Ferreira Mendes denomina de dessubjetivização 44 das formas processuais constitucionais, isto é, do afastamento das demandas em torno de questões de constitucionalidade da feição subjetiva que lhes caracterizava e acarretava a adoção de simples eficácia inter partes.

Pautada nessa e em outras circunstâncias verificadas no papel hoje atribuído ao controle difuso de constitucionalidade, a doutrina e a jurisprudência pátrias passaram a admitir a aplicação da técnica de modulação de efeitos (denominada doutrina prospectiva) às decisões proferidas também em sede de controle concreto, desde que respeitados os mesmos pressupostos daqueles expressamente previstos em relação ao controle abstrato.

Justificando a necessidade de se utilizar a doutrina prospectiva nessa seara, Gilmar Ferreira Mendes, na obra já citada, busca amparo no direito comparado para discorrer a respeito:

\footnotetext{
43 Instituto criado a partir da Emenda Constitucional no $45 / 2004$ e regulamentado pela Lei 11.418/o6, o qual atribuiu eficácia erga omnes aos julgamentos proferidos pelo STF em sede de controle difuso de constitucionalidade quando a questão de direito neles debatida ostentar relevância do ponto de vista econômico, político, social ou jurídico, que ultrapassem os interesses subjetivos da causa. Sobre o instituto da repercussão geral no Supremo Tribunal Federal, ver: MENDES, COELHO e BRANCO, op. cit., pg. 1126.

44 MENDES, COELHO e BRANCO, op. cit., pg. 1047
} 
"Embora a Lei 9.868, de 10-11-1999, tenha autorizado o Supremo Tribunal Federal a declarar a inconstitucionalidade com efeitos limitados, é lícito indagar sobre a indagar sobre a admissibilidade do uso dessa técnica de decisão no âmbito do controle difuso.

(...) A declaração de inconstitucionalidade in concreto também se mostra passível de limitação de efeitos. A base constitucional dessa limitação - necessidade de um outro princípio que justifique a não-aplicação do princípio da nulidade - parece sugerir que, se aplicável, a declaração de inconstitucionalidade restrita revela-se abrangente do modelo de controle de constitucionalidade como um todo. É que, nesses casos, tal como já argumentado, o afastamento do princípio da nulidade da lei assenta-se em fundamentos constitucionais e não em razões de conveniência. Se o sistema constitucional legitima a declaração de inconstitucionalidade restrita no controle abstrato, essa decisão poderá afetar, igualmente, os processos do modelo de controle concreto ou incidental de normas.

(...) Não parece haver dúvida de que, tal como já exposto, a limitação de efeito é decorrência do controle judicial de constitucionalidade, podendo ser aplicada tanto no controle direto quanto no controle incidental." 45

Luís Roberto Barroso, na mesma linha de entendimento, acrescenta que a aplicação da doutrina prospectiva em sede de controle difuso, muito embora seja comumente verificada a partir da aplicação analógica dos artigos 27 e 11 das Leis $\mathrm{n}^{\mathrm{o}} \mathrm{s}$ 9.868/92 e 9.882/93, independe de sua invocação, tendo em vista que a possibilidade de ponderação de valores e de bens jurídicos constitucionais não pode estar vinculada à existência de previsão legal.

Ao tratar do tema, o autor propõe uma sistematização das hipóteses em que a utilização da técnica da modulação de efeitos seria admissível à luz do ordenamento jurídico brasileiro, conferindo especial atenção às hipóteses de modificação da jurisprudência, que representam um elevado risco ao postulado constitucional da segurança jurídica. Em suas palavras:

"Na linha da jurisprudência do STF, a modulação temporal dos efeitos de decisão judicial pode ocorrer em quatro hipóteses: a) declaração de inconstitucionalidade em ação direta; b) declaração incidental de inconstitucionalidade; c) declaração de constitucionalidade em abstrato; e d) mudança de jurisprudência”. 46

45 MENDES, COELHO e BRANCO, op. cit., pg. 1043-1045

46 BARROSO, Luís Roberto. Mudança da Jurisprudência do Supremo Tribunal Federal em Matéria Tributária: Segurança jurídica e modulação dos efeitos temporais das decisões judiciais. Revista de Direito do Estado, 2:261, 2006 
Essas hipóteses, especialmente a decorrente de modificação de jurisprudência, serão objeto de análise mais aprofundada adiante. Por ora, espera-se ter demonstrado, de forma sucinta e sem preocupações exaurientes, as principais características dos modelos de controle de constitucionalidade e a sua importância na manutenção dos pressupostos do Estado de Direito.

Por figurar como mecanismo de concretização dos pressupostos da Distinção de Poderes e da Supremacia da Constituição e, além disso, garantidor de direitos fundamentais do cidadão que eventualmente venham a ser suprimidos ou indevidamente limitados pelo legislador, impõe-se que seu exercício se dê de forma que a correção de um vício de inconstitucionalidade não sacrifique outros valores constitucionais igualmente relevantes para a formação e estruturação do Estado de Direito.

Nesse contexto, insere-se a doutrina da modulação de efeitos das decisões tomadas em sede de controle de constitucionalidade, cujos pressupostos e origens históricas se alinham aos princípios e ideais burgueses que permitiram o surgimento do constitucionalismo moderno, consoante restará demonstrado a seguir.

\subsection{Os fundamentos e pressupostos da doutrina prospectiva: modulação de efeitos como mecanismo de afirmação de direitos do cidadão}

O surgimento e desenvolvimento da doutrina prospectiva no direito comparado revela, de plano, que a pretensão de atribuir eficácia futura às decisões tomadas em sede de jurisdição constitucional, relativizando a tradicional teoria da nulidade, sempre encontrou justificativa na necessidade de se proteger os direitos dos cidadãos contra os atos potencialmente lesivos praticados pelo Estado. 
Tal justificativa se confunde com as próprias justificações históricas da formação do Estado de Direito, nos termos em que explicitado no início deste trabalho. Essa constatação, por si, corrobora o entendimento de que sua aplicação, atualmente, deve estar comprometida com as razões pelas quais foi concebida historicamente.

Fábio Martins de Andrade, em obra específica sobre a possibilidade de modulação de efeitos em matéria tributária no Brasil47, estabelece um panorama internacional em torno da experiência jurídica de surgimento da doutrina prospectiva. Ao passar pelo Tribunal Constitucional alemão, a Suprema Corte americana e as Cortes Constitucionais de Portugal e da Espanha, relata que sua aplicação se vincula, desde sua origem, à afirmação de direitos do cidadão.

As primeiras aparições da técnica de modular os efeitos das decisões tomadas em controle de constitucionalidade remontam ao caso Linkletter $v$. Walker, julgado pela Suprema Corte Americana em 1965, no qual se decidiu que a Constituição não determinava nem proibia a adoção de efeitos retroativos. ${ }^{4}$ Ainda que a maioria dos casos analisados pela então Corte de Warren ${ }^{49}$ se referisse à aplicação de leis criminais, certo é que a utilização da doutrina prospectiva era utilizada como forma de defesa de direitos civis ainda não consolidados.

Sobre o papel daquela Corte nessa construção de direitos e na inauguração da doutrina prospectiva, Saul Tourinho Leal salienta que

"A doutrina prospectiva não pode ser desvirtuada ao oposto do que ela verdadeiramente representa. A medida, na sua versão originária, teve por finalidade implementar decisões inovadoras proferidas pela "Corte de Warren", nos Estados Unidos, assegurando direitos fundamentais ainda não reconhecidos pela Suprema Corte e alvo de omissão por parte dos Poderes Públicos.

\footnotetext{
47 ANDRADE, Fábio Martins. Modulação em Matéria Tributária: o argumento pragmático ou consequencialista de cunho econômico e as decisões do STF. Quartier Latin: São Paulo, 2011.

48 Sobre os detalhes do julgamento, ver: ANDRADE, Fábio Martins, op. cit., pgs. 219 a 226.

49 Forma como era denominada, à época, a Suprema Corte Americana, em referência ao Chief Justice Earl Warren.
} 
Como a Corte vinha garantindo inúmeros direitos civis, precisou-se de um mecanismo para que o Estado se preparasse administrativamente para implementá-los.

Assim, passou-se a possibilitar, ao lado da decisão de inconstitucionalidade com efeitos retroativos amplos ou limitados, a superação prospectiva. Essa, pode ser: i) Limitada: aplicável aos processos iniciados após a decisão, inclusive ao processo originário; ii) Ilimitada: inaplicável ao processo que lhe deu origem.

Na jurisprudência norte-americana, a origem da postura se dá no caso Linkletter v. Walker, 381 U.S. 618 (1965). Nele, a Suprema Corte, após estabelecer que a Constituição não exigia, nem proibia, a declaração de inconstitucionalidade com efeito retroativo, estabeleceu que deveriam ser ponderados, caso a caso, os méritos e deméritos de uma ou outra solução, com atenção para a história do ato normativo debatido, sua finalidade e efeito, bem como as conseqüências da retroatividade. Como já dito, a ponderação se deu num ambiente que caminhava em largos passos rumo a assegurar direitos civis (....." 50

Esses pressupostos se coadunam com tudo o que foi exposto acerca da ratio essendi do próprio Estado de Direito. Pautando-se na premissa basilar de que seu objetivo reside na proteção do indivíduo frente ao Estado, cujos poderes serão limitados pela própria Constituição que o rege, chega-se à constatação de que o instrumento da modulação de efeitos, como forma de concretizar valores e princípios constitucionais, está condicionada à realização desses propósitos.

Em razão disso, a moderna doutrina nacional dedicada ao estudo da segurança jurídica e da forma como ela foi empregada nos artigos 27 e 11 das Leis 9.868/92 e 9.882/93 vem definindo que o termo, muito embora tenha sido empregado, a princípio, como um conceito jurídico indeterminado, de conteúdo aberto a ser preenchido com certa margem de valoração, deve ser entendido no sentido da proteção do indivíduo, de acordo com a lógica constitutiva do ordenamento. Nesse contexto, Fábio Martins de Andrade afirma que

"A noção de segurança jurídica é um conceito jurídico indeterminado e que, por isso mesmo, não conta com definição clara e incontroversa. Mesmo permanecendo um conceito vago e ambíguo, a doutrina já logrou identificar o que pode ser chamado de seu 'núcleo conceitual', cuja palavra chave é previsibilidade.

$5^{\circ}$ LEAL, Saul Tourinho. Modular para não pagar: a adoção da doutrina prospectiva negando direitos aos contribuintes. In: Revista Dialética de Direito Tributário n. ${ }^{\circ}$ 158, novembro 2008, p. 78-86) 
A previsibilidade (...), por sua vez, desdobra-se em duas dimensões distintas, quais sejam, a certeza quanto à norma aplicável às relações sociais que estabelecem (certeza jurídica ou estabilidade e a expectativa ou confiança quanto à situação de cada um nas relações sociais de que participa (proteção da confiança).

(...) Verifica-se, portanto, que, na aplicação do art. 27 da Lei $n^{0}$ 9.868/99, a proteção da confiança exerce papel relevante no exame da eventual modulação temporal dos efeitos da decisão quanto à limitação material relacionada às 'razões de segurança jurídica'."51

Em complemento, acrescente-se que a noção de proteção da confiança, subprincípio da segurança jurídica já tratado anteriormente, só pode ser entendida sob a ótica da confiança do cidadão, já que, evidentemente, não haveria qualquer sentido em se pretender conferir proteção do Estado em relação aos seus próprios atos.

É cediço que a proteção da confiança possui a finalidade de assegurar os direitos e expectativas dos indivíduos em face das manifestações estatais, especialmente quando ocorrem modificações nessas manifestações. Tanto que, conforme relembra Fábio Martins de Andrade, a importância axiológica e a densidade constitucional da proteção da confiança na garantia dos direitos fundamentais dos cidadãos enseja o seu prevalecimento sobre outros valores que não ostentem o caráter de fundamentais e, mesmo dentre esses, tende a prevalecer caso esteja qualitativamente ligado a outro a outro fundamento constitucional igualmente fundamental. 52

Nesse sentido, Ana Paula Ávila, em estudo sobre os fundamentos da modulação de efeitos no controle de constitucionalidade53, afirma que a modulação não pode ser invocada em benefício do Estado, mas tão somente do indivíduo ou da sociedade. Ao empreender um vasto levantamento de

${ }^{51}$ ANDRADE, Fábio Martins de. Op. cit., pg. 276-278

$5^{2}$ Idem, pg. 280

53 ÁVILA, Ana Paula. A Modulação de Efeitos Temporais pelo STF no Controle de Constitucionalidade: Ponderação e regras de argumentação para a interpretação conforme a Constituição do artigo 27 da Lei no $\mathbf{9 . 8 6 8}$ /99. Porto Alegre: Ed. Livraria do Advogado, 2009. 
precedentes judiciais na tentativa de sistematizar o conceito de segurança jurídica utilizado pelo legislador nas Leis 9.868/92 e 9.882/93, a autora conclui:

\begin{abstract}
"É importante perceber que, em todas essas decisões, apresenta-se um elemento comum: a utilização da segurança jurídica em favor da proteção do cidadão. Isso favorece, em boa medida, a densificação conceitual da expressão razões de segurança jurídica, presente no art. 27 , através [sic] de uma generalização, no sentido de que essas razões somente podem ser invocadas para conferir prevalência aos direitos fundamentais dos indivíduos e, jamais, para perpetuar a lesão, a esses mesmos direitos, em decorrência de norma declarada inconstitucional".54
\end{abstract}

Sendo assim, pode-se extrair, portanto, que as origens e justificativas históricas da modulação de efeitos das decisões em sede de controle de constitucionalidade, bem como os próprios pressupostos extraídos do papel do controle de constitucionalidade e dos Tribunais em geral na realização do escopo do Estado de Direito, apenas autorizam a utilização do instituto quando em benefício dos direitos constitucionalmente assegurados aos cidadãos, isto é, em um contexto de proteção do indivíduo em face do poder estatal.

\title{
2.3 O debate em torno da constitucionalidade do próprio instituto da modulação: ADI's no 2.154/DF e 2.258/DF
}

A despeito dos fundamentos acima expostos no sentido de compatibilizar o instituto da modulação de feitos com a própria garantia de manutenção dos objetivos da Constituição, o surgimento dessa previsão no ordenamento jurídico brasileiro, com a edição da Lei 9.868/99 e 9.882/99, ensejou uma série de questionamentos quanto à sua constitucionalidade.

Nesse contexto, cumpre tecer breves comentários às Ações Diretas de Inconstitucionalidade $\mathrm{n}^{\circ} \mathrm{S} 2.154 / \mathrm{DF}$ e $2.258 / \mathrm{DF}$, ajuizadas, respectivamente, pela Confederação Nacional das Profissões Liberais - CNPL e pelo Conselho Federal da Ordem dos Advogados do Brasil para questionar a constitucionalidade do

54 ÁVILA, Ana Paula, op. cit., pg. 157-163 
artigo 27 da Lei 9.868/99, cujo entendimento adotado será inteiramente aplicável ao artigo 11 da Lei 9.882/99

Ambas essas ações, ajuizadas no ano 2000 com pedido liminar, ainda estão pendentes de julgamento pelo Plenário do Supremo Tribunal Federal e, atualmente, encontram-se apensadas para julgamento conjunto, com um voto já proferido pelo Ministro relator Sepúlveda Pertence, na sessão de 16.08.2007, pela inconstitucionalidade do dispositivo. O julgamento, na ocasião, foi interrompido por pedido de vista da Ministra Carmen Lúcia e, até o momento, ainda não foi retomado.

Nas petições iniciais dessas ADI's, argumenta-se que o artigo 27 da Lei 9.868/99 violaria o próprio Estado Democrático de Direito e os princípios constitucionais da legalidade e, indiretamente, da igualdade, na medida em que a nulidade da lei inconstitucional figuraria como um dos pilares do Estado de Direito, e sua relativização colocaria em xeque a própria Supremacia da Constituição, de forma que jamais poderia ser realizada por lei ordinária.

Todos esses argumentos encontram amparo unicamente em doutrina minoritária, mas não menos conceituada, da qual podem ser citados Ingo Wolfgang Sarlet, Moreira Alves e Ives Gandra da Silva Martins, todos no sentido de que a atribuição de natureza meramente constitutiva negativa à decisão, impossibilitando a retroação de seus efeitos, poderia vir a permitir incontáveis abusos por parte do Estado. Nas palavras de Ives Gandra,

\footnotetext{
"Tal entendimento pode gerar, principalmente no campo do direito tributário, a irresponsabilidade impositiva, com a possibilidade de as exações inconstitucionais, mesmo após a decisão definitiva da Suprema Corte, terem seus inconstitucionais efeitos perpetuados, entendendo-se o Estado - que violentou a Constituição - autorizado a permanecer com o produto da arrecadação ilegítima, pela eficácia ofertada à decisão definitiva". 55
}

55 ÁVILA, Ana Paula, op. cit., pg. 157-163 
Adotando esse entendimento, o Ministro Sepúlveda Pertence, em sua fundamentação para justificar a inconstitucionalidade do referido artigo 27 , em síntese, concluiu que a pretensão de relativizar a teoria da nulidade da lei inconstitucional só poderia ser veiculada por meio de Emenda Constitucional, bem como que, ainda assim, sua aplicação somente poderia ser permitida a partir de uma interpretação conforme à Constituição, evitando-se eventuais violações ao ato jurídico perfeito e à coisa julgada. $5^{6}$

Pela análise dessa argumentação, muito embora tenha sido utilizada para fundamentar posição contrária à legitimidade do instituto da modulação, constata-se que, contrariamente ao que possa parecer, ela não discrepa dos argumentos pelos quais se defende, no presente trabalho, a aplicação unilateral da modulação de efeitos, isto é, em favor unicamente dos direitos dos cidadãos.

Com efeito, nota-se tanto dos argumentos levantados em sede doutrinária quanto dos fundamentos aduzidos pelo Ministro relator das ADI's em comento que o cerne das preocupações em torno do instituto reside na possibilidade de desvirtuamento das conquistas e dos valores individuais democráticos que se consolidaram na luta pela formação do Estado de Direito, fundado na limitação do poder estatal.

Na medida em que se considera, tal como apontado acima, que a modulação de efeitos só tem lugar na defesa e na proteção dos direitos dos cidadãos, não mais subsistem críticas dessa natureza, já que, como dito, a utilização do instituto se daria com o escopo de preservar valores constitucionais de altíssima relevância, em especial o da segurança jurídica e de seus subprincípios.

Vale ressaltar, ainda no debate quanto à constitucionalidade do artigo 27 da Lei 9.868/99, que, não obstante a pendência de julgamento das ADI's em referência, o Supremo Tribunal Federal tem reiteradamente aplicado a modulação de efeitos com base nessa previsão legislativa, o que vem sendo feito

56 MARTINS, Ives Gandra da Silva. MENDES, Gilmar Ferreira. Controle Concentrado de 
ora de forma condizente com os propósitos do instituto, ora nem tanto, o que será objeto de discussão no próximo capítulo.

Dessa forma, a utilização do instituto previsto no dispositivo cuja constitucionalidade ainda será apreciada só pode significar, a nosso ver, que a tendência da Corte, em sua atual composição, é a de considerar constitucional a modulação de efeitos. Caso contrário, estar-se-ia aplicando de forma quase irresponsável um instituto que, em breve, seria extirpado do ordenamento jurídico e, pior, sem a possibilidade de modulação de efeitos (que estaria sendo rechaçada na mesma ocasião), o que acarretaria grande insegurança aos julgados em que o dispositivo foi aplicado.

No entanto, é importante ressaltar que o Supremo Tribunal Federal, no exercício de seu papel constitucional de guardião da Constituição, de seu último intérprete, prescindiria do disposto no artigo 27 em comento para o exercício da faculdade nele prevista, já que, nessa condição, possui competência para ponderar os possíveis impactos negativos de suas decisões sobre os valores jurídicos insculpidos no texto constitucional. Esse é o posicionamento de Fábio Martins de Andrade:

"Com efeito, é possível compreender que a faculdade prevista no art. 27 é despicienda no plano legal, tendo em vista que deflui de modo direto da atividade própria do STF como guardião da Constituição no exercício do controle de constitucionalidade das leis e atos normativos. Essa faculdade decorre, de maneira implícita, do próprio texto constitucional”. 57

E o autor ainda vai além: ao entender que a própria Constituição autoriza implicitamente o exercício da modulação de efeitos, poder-se-ia cogitar da inconstitucionalidade do artigo 27 quanto ao quórum de dois terços nele previsto, eis que o legislador ordinário estaria impondo restrições a uma atividade não limitada pela Constituição Federal.

Constitucionalidade: comentários à Lei 9.868, de 10-11-1999. São Paulo: Saraiva, 2001, pg. 206 57 ANDRADE, op. cit., pg. 347 
Sem pretender aprofundar a análise dessa questão, importa ao presente trabalho a constatação de que, seja pela aplicação do dispositivo legal, seja em virtude da autorização implícita conferida ao Supremo Tribunal Federal pela própria Constituição, certo é que as razões de segurança jurídica ou relevante interesse social a ensejarem a aplicação da doutrina prospectiva devem estar vinculadas à proteção do cidadão, do indivíduo, do contribuinte, enfim, dos titulares de direitos fundamentais voltados à limitação da atuação estatal.

É de suma importância, ainda na linha do pensamento de Fábio Martins de Andrade, que o próprio Supremo Tribunal Federal, reconhecendo a modulação de efeitos como mais um mecanismo de defesa dos valores e princípios inseridos na própria Constituição, venha a estabelecer uma adequada regulamentação do instituto, seja por meio de uma consolidação da jurisprudência em torno dos conceitos abertos utilizados pelo legislador na Lei 9.868/99, seja por meio de projeto de lei de sua iniciativa, na qual sejam estabelecidos parâmetros, limites e restrições a essa faculdade. $5^{8}$

${ }^{58}$ ANDRADE, op. cit., pg. 348 


\title{
3. A modulação de efeitos em matéria tributária
}

O debate em torno da doutrina prospectiva e de sua aplicação às decisões do Supremo Tribunal Federal, no plano prático, recorrentemente envolve a temática tributária, a qual, no direito brasileiro, assume natural vocação constitucional. Sobre o tema, James Marins afirma que

\begin{abstract}
"No Brasil, único país do mundo a contar com um Sistema Constitucional Tributário, o problema das antinomias adota muitíssimas vezes a forma de inconstitucionalidade, o que conduz a importantes desdobramentos e problemas na geração de e aplicação das normas jurídicas tributárias. Diante da generosidade do legislador constitucional brasileiro na inserção de regras tributárias na Constituição Federal de 1988, criando um sistema que se identifica pela hermeticidade, as normas infraconstitucionais tributárias, complementares ou ordinárias, sofrem rigorosas limitações materiais e formais e submetem-se amplamente ao teste da constitucionalidade". 59
\end{abstract}

Dessa forma, seja pela forte atuação do Estado na arrecadação de receitas públicas, seja pela intensa limitação da liberdade individual que o poder estatal de tributar representa no moderno Estado de Direito, as discussões quanto à segurança das relações jurídicas entre Estado e contribuinte tem reiteradamente ensejado o debate em torno da aplicação - ou não - do instituto da modulação de efeitos quando da tomada de decisões na seara tributária. Por essa razão, dedicase o presente estudo, especificamente, à análise da utilização da doutrina prospectiva nessa seara.

\subsection{O contribuinte como cidadão e o princípio da proteção da confiança como corolário da segurança jurídica no Direito Tributário}

No contexto da constitucionalização das normas tributárias, convém salientar que o contribuinte, nas Constituições modernas, foi inserido no conceito de cidadão e, como tal, titular de diversos direitos fundamentais. Saul Tourinho Leal, em ensaio sobre essa temática, afirma que

59 MARINS, James. Direito Processual Tributário Brasileiro (Administrativo e Judicial). $5^{\mathrm{a}}$ Ed., São Paulo: Dialética, 2010, pg. 22. 
"A alocação dos direitos dos contribuintes na sua relação para com o Estado como sendo direitos fundamentais é antiga. A Carta Magna de 1215, nas suas cláusulas 12 e 14 assim o diziam. O Bill of Rigths (1689), também na Inglaterra, trouxe dispositivo semelhante inserto na parte tributária do documento. $\mathrm{O}$ mesmo ocorreu com a Declaração de Independência dos Estados Unidos da América, de 4 de julho de 1776. Também com a Declaração do Povo da Virgínia, de 1787. Numa conotação mais universalista, há a Declaração de Direitos do Homem e do Cidadão, editada em França, em 1789, que amplia a temática tributária não apenas para exigir consentimento, mas também para permitir uma apreciação de elementos essenciais do tributo, como a base de cálculo da alíquota." 60

\section{O mesmo raciocínio é desenvolvido por Manuel Cavalcante Lima Neto:}

O reconhecimento dos direitos humanos, sob o ponto de vista do direito positivo, tem o seu alvorecer na história cartas e declarações de direitos para depois passar a integrar as constituições de diversos países.

Compondo as reivindicações de proteção dos que sempre estiveram sujeitos ao poder do Estado, nas suas variadas configurações, assume lugar de destaque a questão da tributação. Os excessos e a falta de controle sobre o ato de instituir e majorar tributos serviram de móvel para a introdução de limitação ao exercício desse poder de tributar, o que se demonstra pela presença de dispositivos direcionados a exigir a aprovação das assembléias ou parlamentos para a instituição de tributos nas principais cartas e declarações de direitos, primeiras manifestações formais que deram impulso ao reconhecimento do que atualmente se concebe como direitos fundamentais específicos para proteção dos contribuintes. ${ }^{61}$

Como se vê, dentre os princípios concretizadores do escopo de limitar a atuação do Estado e de garantir um equilíbrio de forças entre ele e os cidadãos, ocupam posição de destaque aqueles que dizem respeito às limitações ao poder de tributar. Na Constituição brasileira, nesse sentido, dentre princípios implícitos e explícitos, podem ser mencionados a legalidade (tipicidade) e a irretroatividade

6o PISANI, José Roberto; LEAL, Saul Tourinho. Modulação de efeitos em matéria tributária: "ICMS na base da COFINS"; "prescrição previdenciária"; e "COFINS: sociedades civis". Revista Fórum de Direito Tributário, Belo horizonte, v. 6, n. 36, nov. 2008, pg. 101-122

61 LIMA NETO, Manuel Cavalcante. Direitos fundamentais dos contribuintes: limitações constitucionais ao poder de tributar. Recife: Nossa Livraria, 2005, p.116. 
tributárias, a não-surpresa, a capacidade contributiva e, em especial, a proteção da confiança do contribuinte.

Portanto, não restam dúvidas de que direitos dos contribuintes são, sobretudo, direitos do cidadão e, por assim dizer, direitos fundamentais. Segundo a lição de Schmitt, tratada no primeiro capítulo, tais direitos figuram como elementos norteadores da limitação ao poder do Estado, de forma a garantir a proteção de uma esfera de liberdade e de segurança aos indivíduos.

Nesse contexto, no que importa ao presente trabalho, evidencia-se que o instituto da modulação de efeitos, uma vez considerado como mecanismo de proteção de direitos fundamentais do cidadão, figurará como um importante elemento na garantia da segurança das relações jurídicas firmadas entre os entes tributantes estatais e o contribuinte.

Nesse sentido, Geraldo Ataliba, em sua obra República e Constituiçãón ${ }^{62}$, resgata as noções idealizadas por Schmitt para concluir que o ideário de Estado de Direito consolidado no mundo ocidental a partir do final do século XVIII criou um sistema fundamentalmente incompatível com a surpresa, isto é, com a falta de previsibilidade da ação estatal pelos cidadãos, a qual se confunde, inegavelmente, com a idéia de abuso de poder.

Empreendendo uma análise dessas questões sob a ótica do direito tributário, o autor salienta que esse abuso de poder do Estado, em desrespeito aos postulados da segurança e da não-surpresa, ganha contornos mais nítidos quando se trata de arrecadação de tributos. Segundo afirma,

"É em matéria tributária que mais freqüentemente se vê o Estado tentado a alterações bruscas e implantação de inovações, surpreendendo o cidadão. Daí porque foi a esse propósito que surgiram as reações que, à sua vez, deram lugar a momentos tão decisivos na história do constitucionalismo. Em 1215, a Magna Charta Libertatum, com decisiva motivação tributária; a Declaração de Independência dos Estados Unidos, desencadeada pelo Stamp Act; a nossa Inconfidência Mineira, com toda uma bela proposta republicana e federal... Tudo

${ }^{62}$ ATALIBA, Geraldo. República e Constituição. Malheiros editores, $2^{\mathrm{a}}$ ed., São Paulo: 2001 
a mostrar que a tendência ao abuso de poder tem significativo e amplo campo de expansão na seara tributária”. ${ }^{63}$

Por essa razão, é no campo do direito tributário que o princípio da proteção da confiança ganha importância ainda mais sensível. Aqui, ele se torna instrumento central de limitação ao poder do Estado de instituir ou majorar tributos de forma arbitrária, isto é, sem respeitar os postulados da anterioridade, da irretroatividade e da capacidade contributiva.

É importante lembrar, à luz de tudo o que foi exposto nos capítulos anteriores, que os Tribunais possuem papel fundamental na formação da confiança no direito. É nesse contexto que se vislumbra a modulação de efeitos, especialmente em matéria tributária, unicamente como mecanismo de concretização dos princípios da segurança jurídica e da proteção da confiança do contribuinte.

No entanto, conforme será demonstrado adiante, a utilização do instituto pelo Supremo Tribunal Federal, em sede de controle de constitucionalidade difuso ou concentrado, nem sempre tem atentado para a circunstância de que os fundamentos da doutrina prospectiva, suas origens históricas e suas justificativas conceituais perante a concretização dos ideais do Estado de Direito orientam a sua aplicação unilateral em defesa do cidadão.

\subsection{Modulação de efeitos no controle de constitucionalidade em matéria tributária: análise crítica da sua evolução na jurisprudência do Supremo Tribunal Federal}

A utilização da doutrina prospectiva pelo Supremo Tribunal Federal, nos últimos anos, veio conquistando cada vez mais espaço nos debates travados no Plenário daquela Corte, especialmente diante de julgamentos emblemáticos que importavam em grandes transformações no cenário político e jurídico nacional,

${ }^{63}$ ATALIBA, op. cit., pg. 172 
tendo grande parte dessas discussões sido travadas no âmbito de questões tributárias.

Essas deliberações, debatidas em questões de ordem após o resultado final dos respectivos julgamentos, revelam que a utilização do instituto ainda carece de fundamentos e diretrizes que lhe dêem substância, à luz do papel da modulação de efeitos na garantia da segurança jurídica protegida constitucionalmente.

Sem maiores preocupações quanto às questões de mérito debatidas em cada um dos casos, as quais serão resumidamente mencionadas para fins de compreensão do tema, demonstrar-se-á, a seguir, três precedentes do Tribunal em que se utilizou o instituto de formas diversas, mas que revelam, no entanto, um direcionamento evolutivo no sentido de conferir ao mecanismo da modulação de efeitos o seu verdadeiro significado.

\subsubsection{0 caso Prescrição Previdenciária: modulação de efeitos em benefício do Estado}

$\mathrm{Na}$ assentada de 11 de junho de 2008, o Supremo Tribunal Federal levou a julgamento os Recursos Extraordinários $\mathrm{n}^{0} \mathrm{~S}$ 556.664, 559.882 e 560.626, nos quais se discutia, em controle difuso, a constitucionalidade dos artigos 45 e 46 da Lei $\mathrm{n}^{\circ} 8.212 / 91$ e $5^{\circ}$, parágrafo único, do Decreto-Lei 1.569/77, que estipulavam prazo decadencial e prescricional de 10 anos, respectivamente, para que a Seguridade Social constituísse créditos tributários relativos a suas Contribuições e empreendesse sua cobrança por meio de inscrição em dívida ativa.

Na linha da orientação que já vinha sendo manifestada pela própria Corte em reiterados precedentes, até mesmo em decisões monocráticas ${ }^{64}$, entendeu-se pela inconstitucionalidade dos dispositivos questionados, sob o entendimento de que lei ordinária não poderia alterar normas gerais de direito tributário previstas em lei complementar (Código Tributário Nacional).

64 Ver Recursos Extraordinários 456750, 534856, 544361, 548785, 522824, Rel. Min. Eros Grau; 522757, Min. Carlos Britto; 559991 e 560115, Min. Celso de Mello; e 537657, 552710, 546046 e 540704, Min. Marco Aurélio. 
Na ocasião, a Procuradoria da Fazenda Nacional pleiteou a aplicação do instituto da modulação de efeitos sob o argumento de que a decisão que considerou inconstitucional o prazo de 10 anos, reduzindo-o para cinco, nos termos do Código Tributário Nacional, implicaria em um prejuízo da ordem de 96 bilhões aos cofres públicos, a serem restituídos aos contribuintes na pela via da repetição de indébito. Comentando o julgamento, o jurista Sacha Calmon Navarro Coelho afirmou que

\begin{abstract}
"A Procuradoria da Fazenda Nacional havia se pronunciado, durante o julgamento, alegando que a questão envolve $\mathrm{R} \$ 96$ bilhões, entre valores já arrecadados e em vias de cobrança pela União com base nas leis declaradas inconstitucionais. É o velho e surrado argumento ad terrorem de todos os fiscos: tentam influenciar os juízes com 'as razões de Estado'. Ora, quem mandou o Legislativo afrontar a Constituição com um projeto de lei inspirado pelo Executivo Federal, assinado pelo Presidente da República? Quem mandou cobrar com base em lei inconstitucional? Desde o início, os advogados alertaram que só lei complementar poderia prever as normas gerais de direito tributário". ${ }^{65}$
\end{abstract}

Não foi levantado, em momento algum, quaisquer razões de segurança jurídica ou de quebra da confiança depositada no Tribunal ou no Poder Judiciário como um todo, que já vinha dando sinais claros da inconstitucionalidade dos referidos dispositivos. Não se verificava, portanto, qualquer tipo de surpresa, alteração de interpretação ou mudança de jurisprudência, muito menos em detrimento dos cidadãos/contribuintes, únicas hipóteses passíveis de legitimar a intervenção do Supremo Tribunal Federal na produção de efeitos da declaração de inconstitucionalidade.

No entanto, em que pese todas essas circunstâncias, o Tribunal houve por bem, por maioria, vencido apenas o Ministro Marco Aurélio, conferir eficácia prospectiva à decisão, considerando legítimos os recolhimentos já efetuados e não

\footnotetext{
65 COELHO, Sacha Calmon Navarro. STF Reconheceu que só lei complementar regula matéria tributária. Revista Consultor Jurídico. 23.06.2008. Disponível em: www.conjur.com.br/2008-jun23/lei_complementar_regular_materia_tributaria. Acesso em: 25.06.2011
} 
impugnados até a data da conclusão do julgamento, nos termos da seguinte ementa:

“PRESCRIÇÃO E DECADÊNCIA TRIBUTÁRIAS. MATÉRIAS RESERVADAS A LEI COMPLEMENTAR. DISCIPLINA NO CÓDIGO TRIBUTÁRIO NACIONAL. NATUREZA TRIBUTÁRIA DAS CONTRIBUIÇÕES PARA A SEGURIDADE SOCIAL. INCONSTITUCIONALIDADE DOS ARTS. 45 E 46 DA LEI 8.212/91 E DO PARÁGRAFO ÚNICO DO ART. $5{ }^{\circ}$ DO DECRETO-LEI 1.569/77. RECURSO EXTRAORDINÁRIO NÃO PROVIDO. MODULAÇÃO DOS EFEITOS DA DECLARAÇÃO DE INCONSTITUCIONALIDADE.

I. PRESCRIÇÃO E DECADÊNCIA TRIBUTÁRIAS. RESERVA DE LEI COMPLEMENTAR. As normas relativas à prescrição e à decadência tributárias têm natureza de normas gerais de direito tributário, cuja disciplina é reservada a lei complementar, tanto sob a Constituição pretérita (art. 18, § $1^{\circ}$, da $\mathrm{CF}$ de 1967/69) quanto sob a Constituição atual (art. 146, b, III, da CF de 1988). Interpretação que preserva a força normativa da Constituição, que prevê disciplina homogênea, em âmbito nacional, da prescrição, decadência, obrigação e crédito tributários. Permitir regulação distinta sobre esses temas, pelos diversos entes da federação, implicaria prejuízo à vedação de tratamento desigual entre contribuintes em situação equivalente e à segurança jurídica

(....) IV. RECURSO EXTRAORDINÁRIO NÃO PROVIDO. Inconstitucionalidade dos arts. 45 e 46 da Lei 8.212/91, por violação do art. 146, III, b, da Constituição de 1988 , e do parágrafo único do art. $5^{\circ}$ do Decreto-lei 1.569/77, em face do $\S 1^{\circ}$ do art. 18 da Constituição de 1967/69.

V. MODULAÇÃO DOS EFEITOS DA DECISÃO. SEGURANÇA JURÍDICA. São legítimos os recolhimentos efetuados nos prazos previstos nos arts. 45 e 46 da Lei 8.212/91 e não impugnados antes da data de conclusão deste julgamento."

(STF - PLENO, RREE 556664, 559882 e 560626, Rel. Min. Gilmar Mendes, DJe de 28.11.2008 - grifo nosso)

Os limitados argumentos utilizados pelos Ministros da Suprema Corte, à exceção do Ministro Marco Aurélio, se pautaram na afirmação de que a modulação teria lugar em face da "repercussão e insegurança jurídica que se pode ter na hipótese". Faltou, a toda evidência, sustentação jurídica para se autorizar a modulação, o que se revela ainda mais grave quando se verifica tratarse de instituto excepcionalíssimo, circunscrito às hipóteses de defesa de valores e princípios superiores e anteriores ao Estado, quais sejam, os direitos fundamentais dos cidadãos. 
No bojo das incontáveis críticas formuladas após o julgamento, Fábio Martins de Andrade se insurge ${ }^{66}$ contra a falta de motivação de uma decisão que, por se tratar de tema tão delicado e de aplicabilidade restrita, deveria ser especialmente motivada.

Com efeito, não são necessários maiores esforços para se constatar a circunstância de que não se faziam presentes quaisquer dos elementos autorizadores da modulação dos efeitos da decisão. Tratou-se unicamente de reafirmação de jurisprudência já consolidada no Tribunal, até mesmo manifestada em relação a outras matérias semelhantes, há várias décadas. Além disso, não há que se falar em insegurança jurídica para o Estado, responsável pela inserção das normas jurídicas no ordenamento e por sua aplicação. Tratou-se, na hipótese, de mera pacificação, em última e irrecorrível instância, do entendimento aplicado nacionalmente a respeito da matéria.

Ironizando os argumentos suscitados na ocasião do julgamento, Fábio Martins de Andrade, resgatando as idéias de Andrei Pitten Velloso67, salienta que

\begin{abstract}
"Para a adequada compreensão da 'insegurança jurídica' rapidamente mencionada nos votos 'relâmpago' que a levantaram, é preciso conjugá-la com o real fundamento 'jurídico-constitucional' da decisão: o interesse fazendário. Nesse sentido, cabe assinalar que o Supremo Tribunal Federal optou por dissimular o real fundamento de sua decisão, referindo-se à segurança jurídica quando, na realidade, designava os interesses pecuniários do Fisco. É inquestionável que não se preteriu a primazia da Constituição em favor de um princípio jurídico-constitucional, senão em razões de conveniência econômica, justamente aquelas razões que, segundo o voto condutor, seriam inidôneas para tanto". 68
\end{abstract}

Nesse sentido, encampa-se o entendimento do autor ao se considerar que o fundamento da modulação de efeitos, tal como exposto acima, não pode se

\footnotetext{
${ }^{66}$ ANDRADE, op. cit., pg. 427

67 VELLOSO, Andrei Pitten. A Temerária Modulação dos Efeitos da Pronúncia de Inconstitucionalidade em Matéria Tributária. Revista Dialética de Direito Tributário. São Paulo: Dialética, nº 157, out. 2008.

${ }^{68}$ ANDRADE, op. cit., pg. 428-429
} 
confundir com argumentos consequencialistas de cunho econômico, mormente em se tratando de interesses financeiros do próprio Estado, e não dos contribuintes. Não há que se falar em riscos da insegurança jurídica ao próprio agente cuja atividade é limitada e controlada em nome da segurança jurídica ou, em outras palavras, não se vislumbra a necessidade de proteção daquele contra o qual se deve proteger a sociedade em vista do desequilíbrio de forças naturalmente existente, o qual, no Estado de Direito, é contrabalanceado pela Distinção de Poderes e pelas garantias fundamentais do cidadão.

Ademais, no caso em análise, admitir-se a modulação de efeitos, em 2008, da declaração de inconstitucionalidade de dispositivos cuja entrada em vigor remonta ao ano de 1991 representou, em última análise, a legitimação de um enriquecimento ilícito por parte do Estado, que foi autorizado a se beneficiar da própria torpeza (na contramão do postulado universal do direito) para manter em seu poder um exorbitante montante de tributo indevidamente recolhido dos contribuintes. Na conclusão de Fábio Martins de Andrade,

\footnotetext{
"A modulação temporal dos efeitos da desta decisão parece ter violado de maneira frontal os princípios constitucionais da isonomia e da segurança jurídica, bem como significou evidente ruptura com o modo pelo qual a Corte vinha se debruçando ao tema (em outros julgados). Sucumbiu ao argumento pragmático ou consequencialista de cunho econômico". 69
}

\subsubsection{0 caso COFINS - Sociedades Civis: recusa de modulação de efeitos em benefício dos contribuintes}

Poucos meses após a conturbada decisão proferida em relação aos prazos de prescrição e decadência tributárias e ainda no alvorecer das mais severas críticas à posição adotada pela Corte quanto à modulação dos efeitos daquela decisão, o Supremo Tribunal Federal foi submetido, novamente, a pedido de que se utilizasse da doutrina prospectiva, desta vez requerida pelos contribuintes.

69 Idem, op. cit., pg. 431 
A discussão em debate, travada no $\mathrm{RE}$ 377.457, residia em torno da constitucionalidade da revogação da isenção da COFINS (anteriormente concedida às sociedades civis de prestação de serviços de profissão regulamentada pela Lei Complementar $\mathrm{n}^{0}$ 70/91) pelo artigo 56 da Lei $\mathrm{n}^{0}$ 9.430/96, Lei Ordinária.

É importante esclarecer que essa matéria, anteriormente à admissão e ao julgamento desse recurso extraordinário pelo Tribunal, vinha sendo reiteradamente considerada pela Corte como de índole infraconstitucional, insuscetível, portanto, de conhecimento na via extraordinária, dada a existência de violação meramente indireta ou reflexa ao texto constitucional.

Essa circunstância, aliada ao fato de que o Superior Tribunal de Justiça, no exercício de seu papel constitucional de guardião da legislação federal infraconstitucional, havia pacificado o entendimento sobre a matéria nos termos do enunciado sumular $\mathrm{n}^{0} 276$ daquele Tribunal70, em sentido favorável aos contribuintes, havia ensejado a formação de uma expectativa legítima nos contribuintes, que depositavam sua confiança nas manifestações reiteradas do Poder Judiciário e, com base nelas, empreendiam todo o seu planejamento tributário.

Ocorre que o Supremo Tribunal Federal, modificando seu posicionamento anterior quanto à admissibilidade da tese na via excepcional, entendeu pela possibilidade de apreciar a questão do conflito entre lei ordinária e lei complementar, entendendo, no mérito, que a Lei Complementar $\mathrm{n}^{0} 70 / 91$, na parte em que instituiu a Contribuição Social, seria apenas formalmente complementar, mas materialmente ordinária, razão pela qual se concluiu pela legitimidade da revogação.

Essa simples e resumida referência ao histórico das questões de mérito em torno do caso já se revelam suficientes para se concluir que, na hipótese,

\footnotetext{
$7^{0}$ Enunciado sumular STJ no 276: "As sociedades civis de prestação de serviços profissionais são isentas da COFINS, irrelevante o regime tributário adotado”.
} 
estavam inequivocamente configurados todos os pressupostos necessários à utilização da modulação de efeitos da decisão que considerava constitucional a revogação anteriormente tida por inconstitucional.

Com efeito, ao se passar a exigir a COFINS dos contribuintes que eram considerados isentos do tributo, estava-se, na prática, criando norma nova de incidência tributária, a qual, necessariamente, deveria estar vinculada à observância do princípio da irretroatividade. Nas palavras de Mizabel Abreu Machado Derzi,

\footnotetext{
"Se, supervenientemente, o Poder Judiciário altera o seu entendimento e muda a sua decisão, escolhendo uma outra solução (antes possível, em razão do leque de significados da cadeia de signos), cria nova norma, específica e determinada. Tal norma equivale a uma nova lei, pois a lei anterior, ainda vigente no sentido formal, tinha sido dotada de um só conteúdo, unívoco, pois sofrera o esvaziamento dos demais sentidos alternativos, por decisão do próprio Poder Judiciário". ${ }^{71}$
}

No entanto, em que pese toda a argumentação levantada pelos contribuintes, a Suprema Corte entendeu, por maioria, pela rejeição do pedido de modulação, pautada principalmente na circunstância de que a temática genérica em torno da desnecessidade de lei complementar para dispor sobre tributos era anterior até mesmo a edição da Lei 9.430/96, não havendo densidade jurídica que justificasse a confiança dos contribuintes na tese que ora era superada.

Ocorre que, se analisada a questão à luz de todos os pressupostos do Estado de Direito discorridos ao longo deste trabalho, certo é que se fazem presentes inúmeros elementos capazes de justificar - e até mesmo impor - a adoção da doutrina prospectiva. Ora, sendo o Superior Tribunal de Justiça um órgão de cúpula do Poder Judiciário em matéria infraconstitucional, e tendo o Supremo Tribunal Federal, por anos, corroborado o entendimento de que a

\footnotetext{
${ }^{71}$ DERZI, Mizabel Abreu Machado. Modificações da jurisprudência no direito tributário: proteção da confiança, boa-fé objetiva e irretroatividade como limitações ao poder de tributar. São Paulo: Noeses, 2009, pg. 586
} 
última palavra sobre a matéria caberia àquele Tribunal, eis que inexistiria questão constitucional a ser dirimida pela Suprema Corte, é evidente que uma abrupta modificação nesse cenário acarreta, se dotada de efeitos retroativos, gravíssima violação à segurança jurídica e ao princípio da proteção da confiança do contribuinte.

Essas considerações foram elucidadas no voto do Ministro Celso de Mello, que, na ocasião, manifestou-se no sentido de deferir o pedido de modulação dos efeitos da decisão. Registrando incisivamente a existência, desde 2003, da Súmula 276 do Superior Tribunal de Justiça, defendeu que

\begin{abstract}
"Esse dado assume, Senhor Presidente, extrema importância, pois coloca em pauta a questão relevantíssima da segurança jurídica, que há de prevalecer nas relações entre o Estado e o contribuinte, em ordem a que as justas expectativas deste não sejam frustradas por atuação inesperada do Poder Público, como sucederia em situações, como a ora em exame, em que se registra clara ruptura de paradigmas, com a prolação de decisão que evidentemente onera a esfera jurídica do sujeito passivo da obrigação tributária.

(...) Os cidadãos não podem ser vítimas da instabilidade das decisões proferidas pelas instâncias judiciárias ou das deliberações emanadas dos corpos legislativos. A instabilidade das decisões estatais, motivada pela ruptura abrupta de critérios jurisprudenciais, que, até então, pautavam o comportamento dos contribuintes cujo planejamento fiscal na matéria em causa traduzia expressão direta do que se continha na Súmula 276/STJ -, não pode nem deve afetar ou comprometer a esfera jurídica daqueles que, confiando em diretriz firmada pelos Tribunais e agindo de acordo com esse entendimento ajustaram, de boa fé, a sua conduta aos pronunciamentos reiterados do Superior Tribunal de Justiça a propósito da subsistência, no caso, da isenção da COFINS" ${ }^{72}$
\end{abstract}

Conforme se extrai dos próprios fundamentos do Estado de Direito, norteadores das lúcidas palavras do Eminente Ministro Celso de Mello, os postulados da segurança jurídica e da proteção da confiança representam mandamentos constitucionais que, obrigatoriamente, devem ser observados pelo Supremo Tribunal Federal, sob pena de violação da Constituição, justamente, no seio das tentativas de preservá-la.

${ }^{72}$ STF - Pleno, RE 377457, Rel. Min. Gilmar Mendes, DJe de 18.12.2008 
Independentemente dos fundados argumentos levantados no sentido de se determinar a modulação de efeitos, a votação, quanto a essa questão, acabou empatada em 5 x 5, quórum insuficiente para tanto. Vale ressaltar que, contra essa decisão, foram opostos embargos de declaração pelo Conselho Federal da Ordem dos Advogados do Brasil, ainda pendentes de julgamento, pugnando pelo reconhecimento da inaplicabilidade do quórum de 2/3 previsto no artigo 27 da Lei 9.868/99 em razão de que o fundamento da modulação de efeitos, no caso, não seria não a declaração de inconstitucionalidade da norma, mas, antes, residiria na modificação de jurisprudência, hipótese que será objeto de maiores considerações mais adiante.

Talvez pela repercussão negativa decorrente da modulação de efeitos no julgamento dos prazos de prescrição e decadência tributárias, os Ministros da Suprema Corte, nessa ocasião, revelaram-se extremamente rigorosos e cautelosos com a possibilidade de modular os efeitos da decisão, mesmo em face de justificativas evidentes a autorizar a medida. No entanto, revela-se, já aqui, um amadurecimento dos debates em torno dos princípios da segurança jurídica e da proteção da confiança do contribuinte, tendo cinco Ministros encampado a tese da possibilidade de modulação, o que representa uma certa evolução, ainda que incipiente, rumo ao reconhecimento dos direitos do cidadão.

\subsubsection{O caso FUNRURAL: recusa de modulação de efeitos em prejuízo do contribuinte}

O caso tributário mais recente julgado pelo Supremo Tribunal Federal em que se discutiu a possibilidade de modulação dos efeitos da decisão ocorreu em fevereiro de 2010, quando da apreciação, pelo Plenário, da constitucionalidade da incidência da Contribuição ao FUNRURAL sobre as receitas de comercialização de produtos rurais.

Na ocasião, o Tribunal reconheceu a inconstitucionalidade do artigo $1^{\circ}$ da Lei no 8.540/92, que deu nova redação aos artigos 12, V e VII, 25, I e II, e 30, IV, 
da Lei no 8.212/91, com a redação atualizada até a Lei $n^{0}$ 9.528/97, o que importa no reconhecimento da impropriedade dos recolhimentos efetuados pelo Estado desde a sua instituição, os quais devem ser restituídos, respeitado o prazo prescricional.

O ponto mais importante desse julgamento, para o presente estudo, reside no fato de que, mais uma vez, a Procuradoria da Fazenda Nacional requereu, após o julgamento, fossem modulados os efeitos da decisão, pautando-se em argumentos conseqüencialistas de cunho econômico vinculados unicamente aos prejuízos que seriam suportados pelos cofres públicos em face das inúmeras repetições de indébito que seriam ajuizadas.

Ocorre que, contrariamente ao ocorrido em 2008, quando do julgamento dos prazos prescricional e decadencial tributários, a Corte rechaçou veementemente a possibilidade de conferir eficácia prospectiva à decisão, o que, nos termos do voto do Ministro Carlos Britto, "implicaria pura e simplesmente na abolição do instituto processual da repetição do indébito", em hipótese na qual não se vislumbrava qualquer ameaça à segurança jurídica ou que ostentasse relevante interesse social, na medida em que não violava os direitos dos contribuintes.

Essa decisão representa, mais do que uma mera aplicação da técnica prevista no art. 27 da Lei 9.868/99, uma retomada do Supremo Tribunal Federal na realização dos direitos do cidadão, ou melhor, na proteção destes, na medida em que a modulação, nesse caso, viria como forma de violar garantias do contribuinte. Sobre o tema, Saul Tourinho Leal afirma que

"A rejeição do pedido fazendário de modulação de efeitos no caso Funrural mostra que a violação à Constituição, quando praticada pelo Estado, é muito mais perversa do que a cometida pelo contribuinte. É que o Estado, confiante na modulação de efeitos, estimula atos legislativos que acarretam obrigações tributárias inconstitucionais. A decisão do Supremo é um reencontro. Um 
reencontro do guardião da Constituição com os direitos fundamentais dos contribuintes". 73

Com efeito, somente com a consideração precípua de que o verdadeiro escopo do Estado de Direito consiste na limitação do poder do Estado e na concretização de direitos do cidadão, ilimitados em princípio, em oposição aos poderes instituídos, limitados em princípio, poder-se-á chegar à conclusão de que o instituto da modulação de feitos, em um Estado de Direito, só é concebível como forma de garantir direitos do cidadão, sob pena de ser desvirtuado para o atendimento de interesses particulares, notadamente estatais, o que subverteria toda a lógica do sistema.

73 LEAL, Saul Tourinho. O Supremo e os direitos dos contribuintes. Valor Econômico, 30.3.2010. Disp. em www.netlegis.com.br/fiscolegis/index.jsp?arquivo=detalhesFiscolegis.jsp\&codb $=7 \& \operatorname{cod}=32938$, acesso em 25.06.2011. 


\section{A modulação de efeitos como garantia das limitações ao poder de tributar}

\subsection{Os princípios da boa-fé, da irretroatividade e da proteção da confiança como limites constitucionais ao poder de tributar: possibilidade de modulação de efeitos em "viradas jurisprudenciais"}

Tratou-se, até o momento, do estudo da aplicação do instituto da modulação de efeitos em sede de controle de constitucionalidade, isto é, em hipóteses nas quais se pode identificar, em cada caso, uma norma que tenha sido declarada inconstitucional ou que tenha sua constitucionalidade reafirmada pelo Poder Judiciário, especialmente pelo Supremo Tribunal Federal.

Nesse contexto, é certo que, em um grande número de casos nos quais se cogita da modulação de efeitos da decisão, a ocorrência de uma modificação de jurisprudência figura como elemento central para que inicie o debate em torno das razões de segurança jurídica que fundamentariam a necessidade de adoção da doutrina prospectiva.

Ocorre que, à luz da própria função de guardião da Constituição atribuída ao Supremo Tribunal Federal, é certo que cabe àquela Corte zelar pela higidez e manutenção das garantias constitucionais, como a segurança jurídica, até mesmo em suas próprias decisões.

Já foi dito neste trabalho, quando da análise da constitucionalidade do artigo 27 da Lei 9.868/99, que a competência outorgada à Suprema Corte para ponderar os possíveis impactos negativos de suas decisões sobre valores e princípios presentes no próprio texto constitucional tornaria despicienda, até mesmo, a previsão legal da possibilidade de modulação de efeitos.

É dessa constatação que surgiu, na doutrina constitucional, o reconhecimento de que a utilização da doutrina prospectiva prescinde da declaração de inconstitucionalidade de uma norma, podendo ser invocada, também, nas hipóteses em que ocorre uma alteração da interpretação conferida a 
determinado dispositivo de lei ou da própria Constituição, mesmo que não se tenha, no caso, uma declaração de inconstitucionalidade.

Isso porque, como também já noticiado, a atividade interpretativa - no Estado de Direito, conferida ao Poder Judiciário - importa na definição do conteúdo da norma, isto é, representa uma escolha, dentre tantas possíveis, de qual será considerado o verdadeiro significado do enunciado normativo. Nesse contexto, não restam dúvidas de que a alteração desse conteúdo, desse significado, pelo próprio Poder Judiciário, pode representar uma eventual afronta à confiança depositada pelos cidadãos no significado anteriormente atribuído à norma.

Essas considerações levaram a doutrina - e até mesmo o próprio Supremo Tribunal Federal - a reconhecer que as hipóteses de modificação de jurisprudência, independentemente da existência ou não de declaração de (in) constitucionalidade, figura dentre as situações em que o próprio ordenamento jurídico não só permite, mas determina que seja ponderada a extensão dos efeitos da decisão que altera o sentido da norma.

Nesse contexto, a eventual retroação dos efeitos de uma nova interpretação (portanto, de uma nova norma), especialmente em matéria tributária, poderá implicar em violação ao princípio da irretroatividade, na medida em que poderá acarretar uma majoração da carga tributária a ser suportada pelo contribuinte ou, pior, estabelecer novos sujeitos passivos de tributos, como, por exemplo, entendendo-se pela limitação da abrangência de determinada regra de isenção ou de não-incidência tributárias.

Mizabel Abreu Machado Derzi, em obra sobre as modificações de jurisprudência no Direito Tributário, afirma que a aplicação dos princípios da irretroatividade, da proteção da confiança e da boa-fé é medida que se impõe como forma de assegurar o prestígio à segurança das relações jurídicas, a qual pode ser facilmente vulnerada pela atividade interpretativa dos Tribunais: 
"O problema da retroação das sentenças se apresenta, então de forma aguda, nas hipóteses de reversão da jurisprudência. Inexistindo alteração da lei ou da Constituição em que se fundou a norma judicial anterior como precedente, igualmente inexistindo alteração na ordem dos fatos, dentro do mesmo grupo de casos similares, que permanece sub iudice, poderá haver nova interpretação judicial criando-se nova norma judicial, com rejeição do precedente. Estaremos em face, assim, de duas normas judiciais contrastantes, a segunda reformando a primeira. Em relação à última norma judicial, modificativa da anterior, é que se colocam, com intensidade, valores e princípios a ponderar, como segurança, irretroatividade, proteção da confiança e boa fé. Somente neste momento poderão ser invocados os princípios da irretroatividade, proteção da confiança e da boa-fé em relação ao Poder Judiciário, pois teremos: (a) uma decisão anterior consolidada, sob a vigência da qual foram concretizados atos e fatos jurídicos, como indutores de confiança; (b) o advento de outro ato, também do Poder Judiciário, nova sentença modificativa da anterior, visto pelo contribuinte como quebra da confiança gerada; (c) a responsabilidade pela violação da segurança/confiança, por meio da proteção de fatos jurídicos, ocorridos no passado, contra a retroação da nova norma judicial". 74

Daí resulta a conclusão da autora de que esses princípios (segurança, irretroatividade, proteção da confiança e boa fé) funcionam como fundamentos da modulação de efeitos das modificações jurisprudenciais danosas ao contribuinte, levando-se em consideração as noções já exaustivamente expostas acima no sentido de que, no Estado de Direito, a proteção do cidadão frente ao Estado é a diretriz para toda estruturação do sistema constitucional. Assim, restaria inserida a modulação de efeitos, portanto, como um verdadeiro mecanismo de garantia das limitações ao poder de tributar.

Nesse contexto, vale mencionar um caso emblemático julgado pelo Supremo Tribunal Federal em matéria tributária, qual seja, o RE 353.657, em que se discutia o direito dos contribuintes ao creditamento do Imposto sobre Produtos Industrializados - IPI incidente sobre a aquisição de matérias primas cujas entradas eram não-tributadas ou tributadas à alíquota-zero.

Nesse julgamento, o Supremo Tribunal Federal, por apertada maioria, havia modificado sua própria interpretação anterior quanto ao artigo $153, \S 3^{\circ}$ da

74 DERZI, op. cit., pg. 586-587. 
Constituição Federal, passando a entender que a Carta Magna não autorizava o direito ao crédito. Suscitada a modulação de efeitos, a Corte entendeu ela não seria cabível por dois motivos: (a) inexistiria coisa julgada a ensejar a formação da confiança dos contribuintes, na medida em que os julgados anteriores do Tribunal ainda não haviam transitado em julgado por força de recursos protelatórios interpostos pela Fazenda Nacional e (b) não havia, no caso, declaração de inconstitucionalidade de nenhuma norma, mas tão somente modificação de interpretação de um mesmo dispositivo constitucional, que continua válido e eficaz.

Quanto ao primeiro óbice, consoante já explicitado acima, é certo que a vulneração da confiança e, conseqüentemente, da segurança das relações jurídicas não se vincula ao trânsito em julgado das decisões judiciais, mas, antes, à postura dos Tribunais em relação a determinado assunto ou matéria.

Dessa forma, constatando que a própria Corte, ainda na pendência de recursos de embargos de declaração contra os julgados que haviam pacificado a matéria, aplicava esses precedentes em decisões monocráticas sob o pálio da sedimentação do entendimento, nada mais justo que se reconheça formada, no mínimo, uma legítima expectativa por parte dos contribuintes de que aquele entendimento não viria a ser alterado. Sobre o tema, Mizabel Derzi afirma que

\footnotetext{
"Esse fato inegável, ausência de coisa julgada a estabilizar o entendimento do Supremo, efetivamente não desencadeia a vigência de uma expectativa normativa, de jurisprudência, sob o domínio da qual tivessem acontecido fatos jurídicos, a merecerem proteção contra a retroação, a partir da vigência da nova decisão.

(...) mas se existe uma plena responsabilidade pelas declarações feitas, até mesmo por informações fornecidas por servidores públicos, é muito mais razoável supor a responsabilidade por despachos e decisões monocráticas de Ministros da Corte Suprema, que aplicam a jurisprudência anterior, como se fosse precedente consolidado. Em decorrência, não se pode falar em irretroatividade, não será a hipótese, mas em proteção da confiança, casada com a boa-fé objetiva.

Ora, com base no $\$ 1^{\mathrm{o}}$-A do art. 557 do Código de Processo Civil que determina possa o relator de um processo decidir, monocraticamente, o recurso interposto, em nome e por delegação do Tribunal, se a Corte Suprema já tiver decidido sobre a constitucionalidade daquela lei ou ato normativo, numerosas decisões monocráticas da Corte foram proferidas, todas julgando os recursos a ela
} 
interpostos. Vários juízes da Corte fizeram acreditar na definitividade do entendimento anterior. Nessas circunstâncias, se não podemos falar em irretroatividade, certamente será totalmente adequado falar em proteção da confiança, por meio da boa-fé objetiva". 75

Quanto ao segundo aspecto, que é, inclusive, objeto específico do presente tópico, vale resgatar a lição de Luís Roberto Barroso sobre o tema, na qual, comentando o emblemático caso "COFINS - Sociedades Civis", também já explicitado, diferencia as hipóteses em que a modulação seria fundada no artigo 27 da Lei 9.868/99 e aquelas nas quais a modulação seria autorizada independentemente da previsão legal, o que afastaria, até mesmo, a necessidade do quórum de 2/3 nele previsto. Em suas palavras,

"O que o STF fez foi modificar o entendimento vigente acerca de matéria tributária, estabelecendo uma nova norma sobre o tema. E norma, consoante a dogmática jurídica contemporânea, não se confunde com enunciado normativo. Enquanto este é o relato abstrato constante do diploma legal, aquela é o produto da interação entre enunciado e realidade fática.

O ponto é especialmente saliente quando se leva em conta que, sobre o tema, havia Súmula do STJ - órgão de cúpula e de uniformização de jurisprudência. E essa nova norma - isto é: o novo entendimento da Corte sobre o tema incrementa a obrigação fiscal a cargos dos contribuintes, a ela se aplicando, como não poderia deixar de ser, a regra constitucional da irretroatividade tributária.

A mesma solução se impõe, ainda, por incidência da proteção da confiança e da boa-fé, que se dirigem de forma específica à Administração Pública e ao Poder Judiciário. Ou seja: ao contrário do que ocorre com a modulação temporal no caso de declaração de inconstitucionalidade de lei ou ato normativo, a eficácia prospectiva postulada aqui não implica paralisação parcial da eficácia de uma norma constitucional. O que ocorre, a rigor, é justamente o oposto. Na realidade, a modulação aqui decorre de forma direta, e necessária, da incidência de normas constitucionais, como a irretroatividade tributária e a proteção da confiança e da boa-fé. Isto é: não se mantém a vigência de um ato inválido, mas evita-se uma inconstitucionalidade. Não faz sentido, portanto, aplicar à hipótese o quorum especial de dois terços: a modulação, no caso concreto, insere-se no âmbito da atuação ordinária do STF como guardião da Constituição. Ainda mais quando para a própria declaração de inconstitucionalidade a Carta de 1988 definiu o quorum de maioria absoluta." 76

75 DERZI, op. cit., pg. 599-600

76 BARROSO, Luís Roberto. Mudança da Jurisprudência do Supremo Tribunal Federal em Matéria Tributária: Segurança jurídica e modulação dos efeitos temporais das decisões judiciais. Revista de Direito do Estado, 2:261, 2006. 
Como se vê, a utilização da doutrina prospectiva é legitimada pelo próprio sistema da Constituição, o qual se revela autopoiético na atividade de assegurar a sua própria manutenção e subsistência. Por essa razão, e considerando-se as origens e justificativas históricas do próprio Estado de Direito, tal como definido por Carl Schmitt, e do papel que a Constituição representa na formação desse Estado, não se vislumbra a sua utilização em detrimento do cidadão, do contribuinte, cuja proteção é o escopo fundamental de sua própria existência.

\subsection{A necessidade de aplicação unilateral da doutrina prospectiva e sua utilização como mecanismo de concretização do princípio da segurança jurídica}

Consoante já mencionado anteriormente, os fundamentos pelos quais a utilização da doutrina prospectiva pode ser considerada legítima nos sistemas constitucionais contemporâneos importa na constatação de que ela só pode ser aplicada em favor dos cidadãos, protegendo-os contra os abusos e arbítrios do poder estatal.

Isso porque, pela construção histórica da afirmação dos direitos burgueses e da formação do Estado de Direito, o princípio da proteção da confiança e da irretroatividade são direitos fundamentais individuais e, como tais, apenas são passíveis de ser reivindicados em contraposição aos Poderes estatais, mas nunca pela própria Administração pública.

Nesse sentido, Mizabel Derzi afirma que os princípios da proteção da confiança, da boa-fé objetiva e da irretroatividade, todos complementares, são verdadeiras limitações ao poder de tributar, apresentando-se como expressão da segurança jurídica. Além disso, e como justificativa dessa constatação, mencionese a circunstância de que a relação de dependência do cidadão em face do Estado, notadamente em seus atos de intervenção e regulação, não encontra 
correspondente sob a ótica do Estado, que certamente possui recursos muito mais amplos e abrangentes para se prevenir de “decepções”. 77

É nesse contexto que a autora resgata as lições de Niklas Luhmann para constatar que todo aquele que se encontra em posição soberana em relação aos fatos e acontecimentos não possui qualquer confiança a ser protegida, já que ele mesmo, no caso, o Estado, tem o domínio sobre os atos praticados por seus três Poderes. 78

Disso decorre, aliás, o entendimento de que a proteção em favor do Estado vulneraria a própria estrutura do Estado de Direito, já que, resguardado por sua eventual confiança, a rigidez dessa estrutura não permitiria, de qualquer forma, que os Poderes estatais fossem colocados em uma posição jurídica mais vantajosa para si em relação ao cidadão, na medida em que a posição ocupada por ele resulta diretamente da Lei, aqui considerada em sentido amplo. Dessa forma, tratando especificamente das alterações jurisprudenciais, mas lançando mão de raciocínio que se aplica à totalidade das hipóteses de aplicação da doutrina prospectiva, a autora conclui:

"O princípio da proteção da confiança e da irretroatividade são princípios e direitos fundamentais individuais, que somente o privado pode reivindicar, em contraposição à Administração pública, ao Poder Legislativo e ao Poder Judiciário, quando os Poderes do Estado criam o fato gerador da confiança. Essa a razão de sua invocação apenas em presença de modificação jurisprudencial em detrimento do contribuinte.

(...) Se as modificações de jurisprudência ocorrem em detrimento das Fazendas Públicas, não se apresentam adequados, então, os princípios da irretroatividade, da proteção da confiança e da boa-fé objetiva, já que são limitações constitucionais ao poder judicial de tributar (...). Mas, evidentemente, a Constituição da República contém os instrumentos necessários para proteger os fatos e atos pretéritos se a alteração jurisprudencial surpreende o ente estatal, projetando-o em verdadeiro estado de necessidade administrativa." 79

Nesse sentido, pode-se afirmar que a segurança jurídica, pilar do Estado de

\footnotetext{
77 DERZI, op. cit., pg. 605

78 Idem, pg. 606

79 DERZI, op. cit., pg. 609
} 
Direito, só pode ser invocada pelos cidadãos, na medida em que, caso reconhecida em favor de interesses estatais, implicaria - necessariamente - na subtração de direitos da coletividade. Sobre o tema, cite-se o entendimento de Ana Paula Ávila:

\begin{abstract}
"Questão interessante é responder se o Estado pode também invocar a segurança jurídica, nesse mesmo aspecto, para a manutenção de situações em que a lei inconstitucional tenha gerado em seu benefício. A resposta é não, taxativamente não, por diversas razões.

Primeiro, porque, se esse benefício se deu em detrimento de direitos fundamentais do indivíduo, já se conclui pela prevalência desses em caso de conflito. Segundo, porque a segurança jurídica é, também, um direito fundamental do cidadão (art. $5^{\circ}$, caput) oponível ao Estado, e o Supremo Tribunal Federal, na esteira do pensamento constitucional germânico, tem confirmado o entendimento de que os direitos fundamentais aproveitam aos cidadãos e, não, ao Estado. E terceiro, porque uma análise mais aprofundada de alguns aspectos do princípio da boa-fé, que, por aqui, tem servido para complementar a segurança jurídica no sentido de proteção da confiança, jamais autorizaria que o autor de um ato inválido pudesse lograr proveito através dele" 80
\end{abstract}

Outro fundamento pelo qual se deve afastar a modulação de efeitos em favor do Estado reside na constatação, trazida por Fábio Martins de Andrade, de que o principal fundamento aduzido nesse sentido reside em argumentação unicamente consequencialista de cunho econômico, conforme já salientado anteriormente, qual seja, aquele fundado nos argumentos ad terrorem relacionados à potenciais catástrofes financeiras ou rombos nos cofres públicos do país. ${ }^{81}$

Ainda que tais argumentos possam ser levados em consideração quando da ponderação sobre os efeitos da decisão judicial, é certo que devem sempre ser encarados como elementos secundários, sob pena de subversão da ordem constitucional que prestigia, fundamentalmente, a proteção do cidadão em face do Estado, e não o contrário.

80 ÁVILA, op. cit., pg. 151-152
81 ANDRADE, op. cit., pg. 364 
Assim, uma vez considerado o verdadeiro papel a ser exercido pelo instituto da modulação de efeitos, especialmente em matéria tributária, resta legitimada sua aplicação unilateral em favor do cidadão e do contribuinte, eis que somente dessa maneira estar-se-á concretizando os valores e pressupostos do Estado de Direito. 


\section{Conclusão}

O estágio em que se encontra a concepção de Estado de Direito nas democracias contemporâneas já não permite que subsistam dúvidas quanto ao papel das Constituições modernas na concretização dos ideais que viabilizaram o seu surgimento. O Estado de Direito, por definição, pressupõe a reunião de esforços no sentido de controlar a atuação estatal, comprometendo-se com a garantia das liberdades individuais e dos demais valores burgueses consolidados com as revoluções liberais dos séculos XVIII e XIX.

Os elementos estruturais hoje considerados como o cerne dos sistemas constitucionais, tais como a Distinção de Poderes e a enumeração de um rol de direitos fundamentais no texto constitucional, justificam-se, fundamentalmente, pela necessidade de limitar o poder do Estado, o que ocorre por meio de um complexo sistema de freios e controles recíprocos do qual o controle de constitucionalidade é parte integrante.

No contexto, figurando o controle de constitucionalidade como um mecanismo de garantia da Supremacia da Constituição e, em última análise, de proteção dos direitos do cidadão frente aos potenciais abusos do Estado, insere-se o instituto da modulação de efeitos como forma de garantir que esses mesmos direitos, sobretudo os inerentes à garantia da segurança jurídica, não restem prejudicados em razão da incongruência e/ou incompatibilidade entre as ações estatais.

Ainda que o elemento da previsibilidade da ação estatal se constitua como um dos mais importantes pressupostos do Estado de Direito, o cidadão não está imune a circunstâncias em que essa previsibilidade é afastada, especialmente em sede de jurisdição constitucional na qual, por vezes, o conteúdo de uma norma de conduta pode ser modificado, seja em virtude da declaração de inconstitucionalidade, seja em razão de uma eventual mudança de orientação jurisprudencial. 
Como forma de corrigir essas distorções, e apenas dessa forma, a utilização da doutrina prospectiva pode e deve ser concebida para assegurar os direitos e garantias do cidadão, aqui considerado o contribuinte. Apenas na realização do escopo precípuo do Estado de Direito, qual seja, o da limitação do poder do Estado, poder-se-á compreender a viabilidade de, em hipóteses excepcionais, modular-se os efeitos de uma decisão da Suprema Corte em benefício da confiança dos cidadãos no Direito e da segurança das relações jurídicas.

Constatado que o STF, nas oportunidades em que se utilizou da doutrina prospectiva, nem sempre levou em consideração os elementos históricos que a justificam, é de se indagar acerca da futura atuação da Suprema Corte no que diz respeito à temática da modulação de efeitos em matéria tributária.

A necessidade de regulamentação do instituto, para além dos conceitos vagos e imprecisos contidos nas Leis que regulamentam o procedimento de controle concentrado de constitucionalidade, é evidente, mas pode ser minimizada a partir da consideração de que a utilização da doutrina prospectiva deve se dar como forma de realização dos direitos do cidadão, concretizando os objetivos do Estado de Direito que, por sua vez, guardam relação necessária com a limitação do poder do Estado.

Uma vez tomada por base essa premissa, cabe ao STF o exercício de seu papel constitucional de guardião da Constituição, protegendo-a, até mesmo, de suas próprias decisões, caso tenham o condão de prejudicar direitos fundamentais.

Como visto, a seleção dos precedentes analisados no capítulo anterior teve por objetivo demonstrar a ocorrência, ainda que relativa, de uma certa evolução no tratamento da doutrina prospectiva pelo Tribunal.

Nesse sentido, encontram-se pendentes de julgamento naquela Corte diversos temas que poderiam ensejar ameaças à confiança dos cidadãos e/ou alterações jurisprudenciais que, conseqüentemente, reclamariam a adoção da 
doutrina prospectiva em benefício dos contribuintes, o que, até o momento, jamais foi feito no STF.

Resta saber se e como o Tribunal Constitucional, reconhecendo o seu verdadeiro papel de guardião não só da Constituição, mas também do próprio Estado de Direito, exercerá sua jurisdição de forma a conferir eficácia máxima aos direitos dos cidadãos. 


\section{Referências Bibliográficas}

AMARAL, Bruno Monteiro de Castro. Segurança Jurídica e Estado de Direito em face da Recorrente Alteração de Posicionamento dos Tribunais Superiores. In: Sistema Tributário Brasileiro: uma visão do presente e do futuro. São Paulo: publicação do XXI Congresso Brasileiro de Direito Tributário promovido pelo Idepe, 2007.

ATALIBA, Geraldo. República e Constituição. Malheiros editores, $2^{\mathrm{a}}$ ed., São Paulo: 2001.

ÁVILA, Ana Paula. A Modulação de Efeitos Temporais pelo STF no Controle de Constitucionalidade: Ponderação e regras de argumentação para a interpretação conforme a Constituição do artigo 27 da Lei no 9.868/99. Porto Alegre: Ed. Livraria do Advogado, 2009.

BANDRÉS, José Manuel. Poder Judicial y Constitución. Barcelona: Casa Editorial, 1987.

BARROSO, Luís Roberto. O controle de constitucionalidade no direito

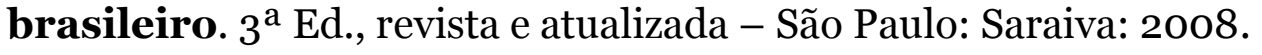

Mudança da Jurisprudência do Supremo Tribunal Federal em Matéria Tributária: Segurança jurídica e modulação dos efeitos temporais das decisões judiciais. Revista de Direito do Estado, 2:261, 2006.

CANOTILHO, José Joaquim Gomes. Direito Constitucional e Teoria da Constituição. $3^{\mathrm{a}}$ ed., Coimbra: Almedina, 1999.

CARVALHO, Paulo de Barros. Segurança Jurídica e Modulação de Efeitos. In: Revista da Fundação Escola Superior de Direito Tributário, Vol. 1, $\mathrm{n}^{0}$ 1. Porto Alegre: 2008.

COELHO, Sacha Calmon Navarro. STF Reconheceu que só lei complementar regula matéria tributária. Revista Consultor Jurídico. 23.06.2008. Disponível em: www.conjur.com.br/2008-jun23/lei complementar regular materia tributaria. Acesso em: 25.06.2011.

DERZI, Mizabel Abreu Machado. Modificações da jurisprudência no direito tributário: proteção da confiança, boa-fé objetiva e irretroatividade como limitações ao poder de tributar. São Paulo: Noeses, 2009. 
DUMONT, Louis. O individualismo: uma perspectiva antropológica da sociedade moderna. Tradução de Álvaro Cabral. Rio de Janeiro: Rocco, 1985.

KELSEN, Hans. Teoria Pura do Direito. Tradução: João Batista Machado. $5^{\mathrm{a}}$ ed. São Paulo: Martins Fontes, 1996.

LEAL, Saul Tourinho. Modular para não pagar: a adoção da doutrina prospectiva negando direitos aos contribuintes. In: Revista Dialética de Direito Tributário n. ${ }^{\circ} 158$, novembro 2008, p. 78-86).

Econômico, O Supremo e os direitos dos contribuintes. Valor http://www netlegis com br/fiscolegis/index.jsp?arquivo=detalhes Fiscolegis jisp $\& \operatorname{codb}=7 \& \operatorname{cod}=32938$, acesso em 25.06.2011.

LIMA NETO, Manuel Cavalcante. Direitos fundamentais dos contribuintes: limitações constitucionais ao poder de tributar. Recife: Nossa Livraria, 2005.

MARTINS, Ives Gandra da Silva. MENDES, Gilmar Ferreira. Controle Concentrado de Constitucionalidade: comentários à Lei 9.868, de 1011-1999. São Paulo: Saraiva, 2001.

MELLO, Celso Antônio Bandeira de. Segurança Jurídica e Mudança de Jurisprudência. In: Revista de Direito do Estado $\mathrm{n}^{\circ}$ 6, ano 2. Rio de Janeiro: abril/junho de 2007.

MENDES, Gilmar Ferreira; COELHO, Inocêncio Mártires; BRANCO, Paulo Gustavo Gonet. Curso de Direito Constitucional $1^{\text {a }}$ ed., São Paulo: Saraiva, 2007.

NERY JUNIOR, Nelson. Boa-fé Objetiva e Segurança Jurídica - Eficácia da Decisão Judicial que Altera Jurisprudência Anterior do Mesmo Tribunal Superior - Efeito ex-nunc e as Decisões do STJ. Barueri: Ed. Manoele, 2008.

GRAU, Eros Roberto. Ensaio e discurso sobre a Interpretação/Aplicação do Direito, $2^{\text {a }}$ Ed., São Paulo: Malheiros: 2003.

Paulo: Malheiros, 2008.

O Direito Posto e o Direito Pressuposto. $7^{\text {a }}$ Ed., São

PISANI, José Roberto; LEAL, Saul Tourinho. Modulação de efeitos em 
matéria tributária: "ICMS na base da COFINS"; "prescrição previdenciária"; e "COFINS: sociedades civis". Revista Fórum de Direito Tributário, Belo horizonte, v. 6, n. 36, nov. 2008, pg. 101-122.

QUEIROZ, Luís César Souza de. Aplicabilidade do princípio da irretroatividade à jurisprudência dos Tribunais Superiores Interpretação e Estado de Direito. São Paulo: Noeses, 2006.

RIBEIRO, Diego Diniz. A Modulação de Efeitos no Controle de Constitucionalidade em Matéria Tributária e a Jurisprudência do STF. In: Revista Dialética de Direito Tributário. São Paulo: Dialética, n. 178, Julho de 2010, pg. 29-30.

ROCHA, Carmen Lúcia Antunes (coord.). "O Princípio da Coisa Julgada e o Vício de Inconstitucionalidade”. Constituição e Segurança Jurídica: Direito Adquirido, Ato Jurídico Perfeito e Coisa Julgada. $2^{\text {a }}$ Ed., Belo Horizonte: Fórum, 2004.

SARLET, Ingo Wolfgang. "A eficácia do direito fundamental à segurança jurídica: dignidade da pessoa humana, direitos fundamentais e proibição do retrocesso social no direito constitucional brasileiro". In: ROCHA, Carmen Lúcia Antunes (Coord.). Constituição e Segurança Jurídica: Direito adquirido, ato jurídico perfeito e coisa julgada. Belo Horizonte, ed. Fórum: 2004.

Porto Alegre: Livraria do Advogado, 2004.

A eficácia dos direitos fundamentais. $4^{\mathrm{a}}$ ed.,

SCHMITT, Carl; AYALA, Francisco (versão espanhola). Teoria de La Constitución. Alianza Editorial S.A., Madrid: 1996

VELLOSO, Andrei Pitten. A Temerária Modulação dos Efeitos da Pronúncia de Inconstitucionalidade em Matéria Tributária. Revista Dialética de Direito Tributário. São Paulo: Dialética, nº 157, out. 2008. 